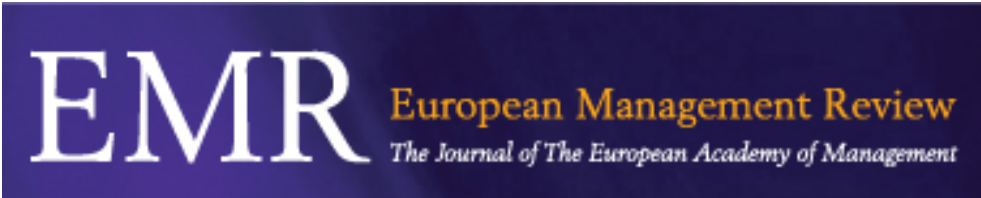

\title{
Doubly Disadvantaged: Gender, Spatially Concentrated Deprivation and Nascent Entrepreneurial Activity
}

\begin{tabular}{|r|l|}
\hline Journal: & European Management Review \\
\hline Manuscript ID & EMR-SI-18-0207.R1 \\
\hline Manuscript Type: & Special Issue \\
\hline Keywords: & $\begin{array}{l}\text { Entrepreneurship < Strategy, Location choice < Entrepreneurship }< \\
\text { Strategy, social policy < Policy, economic policy < Policy }\end{array}$ \\
\hline Additional Keywords: & \\
\hline \multicolumn{2}{|l}{} \\
\hline
\end{tabular}

\section{SCHOLARONE" \\ Manuscripts}




\title{
Doubly Disadvantaged: Gender, Community Deprivation and Entrepreneurial Activity
}

\begin{abstract}
Drawing on human capital, intersectionality and mixed embeddedness theory, we test hypotheses on the relationship between gender differences in human capital and gender differences in early stage entrepreneurial activity at the community level, and the moderating effect of spatial deprivation on this relationship. Using UK data from Global Entrepreneurship Monitor, we find that the disadvantaged position of female entrepreneurs arises from social exclusion, and specifically that the lack of general and specific human capital compared to male counterparts induces the gender differences in entrepreneurial activity. Moreover, this disparity is greater in disadvantaged locations, causing a double disadvantage for women. Our results make a novel contribution to the literature on disadvantage entrepreneurship, and we discuss policy options to tackle double disadvantage at a community level.
\end{abstract}

Keywords: Gender; Social exclusion; Spatial exclusion; Human capital; Entrepreneurship

\section{Introduction}

Research on disadvantage entrepreneurship has explored disadvantages on multiple fronts, including socio-demographics (Carter et al., 2015; Kushnirovich et al., 2017; Marlow and Swail, 2014), entrepreneurial capital (Dodd and Keles, 2014), and location (Naudé et al., 2008; Rouse and Jayawarna, 2006). For instance, we know that in many contexts, individuals belonging to certain social group (e.g. females) are marked by the lack of (or diminished) access to entrepreneurial capital leading to limited entrepreneurial activity (Hughes et al., 2012; Marlow and Patton, 2005). However, we still have limited knowledge on how location disadvantages interact with existing disadvantages at socio-demographic (gender) and entrepreneurial capital (human capital) fronts in influencing entrepreneurial activity (Brush et al., 2017; Gill and Larson, 2014; Henry et al., 2016). To this end, we address the following research question in this paper: what is the effect of community deprivation on gender differences in early stage entrepreneurial activity, accounting for gender differences in human capital at the community level?

There exists a strong economic case for promoting women's entrepreneurship. For instance, one estimate is that if women started businesses at the same rate as men, then the United Kingdom (UK) would see 150,000 more businesses per annum creating 390,000 more 
jobs (UK Women's Enterprise Taskforce, 2012). We also know that harnessing entrepreneurship in disadvantaged areas is critical for enhancing economic development through job creation, increased productivity and social inclusion (Blackburn and Ram, 2006; Welter et al., 2008). Given this relevance of both women's entrepreneurship and entrepreneurship in disadvantaged areas, it is important to have an integrated understanding of how spatial disadvantages (locational) interact with social disadvantages (gender) to influence entrepreneurial activity.

We utilize the literature on human capital, intesectionality and mixed embeddedness to explore the research question. Human capital theory highlights the relevance of two types of human capital on entrepreneurial activity: general (education) and specific (entrepreneurial skills and experience) (Becker, 1976; Marvel et al., 2016). Intersectionality literature discusses priveleges and disadvantages emanating from intersecting social positions of gender, race, and ethnicity (Gill and Larson, 2014; Martinez Dy et al., 2017; Wang and Warn, 2017). Gill \& Larson (2014) extended the intersectionality argument to highlight the intersecting role of place-based effects. The mixed embeddedness approach allows us to explain entrepreneurship by situating the entrepreneurial capabilities and opportunities within a socio-economic, spatial and regulatory context (Jones et al., 2014; Kloosterman, 2010; Ram et al., 2013). A critical element of intersectionality theory is that intersecting social positions have multiplicative rather than additive effects (Dubrow, 2008). We integrate these multiple theoretical strands to argue the presence of a 'double disadvantage' for female entrepreneurs in multiply deprived locations, caused by the interaction of human capital disparities and locational disadvantages.

We use the empirical context of entrepreneurial activity within communities in the United Kingdom to test our arguments. We combine the Global Entrepreneurship Monitor (GEM) database with Index of Multiple Deprivation (IMD) data for the period 2007-2012 to build the dataset. Our results offer support to our argument, highlighting the presence of a 'double-disadvantage' hampering female entrepreneurial activity within communities.

We make multiple contributions through this study. Firstly, we contribute to the literature on disadvantage entrepreneurship (Blackburn and Ram, 2006; Carter et al., 2015; Kloosterman, 2010; Marlow and Swail, 2014; Ram et al., 2013) by highlighting the interaction of social and spatial exclusion on entrepreneurial activity. Secondly, we add to the economic geography literature (Ghani et al., 2013; Langevang et al., 2015; Perucca et al., 2018; Rae, 2012) by exploring the community level effects of gender differences in human capital and 
deprivation on entrepreneurship. Finally, we extend the human capital literature (Estrin et al., 2016; Marvel et al., 2016) by studying the role of gender differences in human capital at a community level rather than at individual, firm or country-level.

\section{Theory and hypotheses development}

The term 'disadvantage entrepreneurship' has been utilized with a range of meanings. Firstly, it could refer to entrepreneurs of a specific group like women (Marlow and Swail, 2014), immigrants (Kushnirovich et al., 2017), ex-prisoners (Cooney, 2012), old people (Curran and Blackburn, 2001), or disabled individuals (Dimic and Orlov, 2014) who experience social exclusion (Khan et al., 2015). Secondly, it can imply the geographical location of individuals and associated spacial inequalities (Naudé et al., 2008) arising from deprivation (Rouse and Jayawarna, 2006). Finally, it might characterise individuals with disadvantages in terms of specific capabilities, skills, or perceptions (i.e. entrepreneurial capital) that enhance their vulnerability, such as discouraged borrowers (Dodd and Keles, 2014; Kon and Storey, 2003). In summary, the disadvantages for entrepreneurs can arise from their socio-economic characteristics, location, or capabilities (Carter et al., 2013).

Prior literature systematically classifies female entrepreneurs as disadvantaged compared to males, highlighting gender disparities in entrepreneurial intentions globally (Hughes et al., 2012; Marlow and Patton, 2005). There is evidence that women exhibit preferences towards flexible working hours, part-time involvement into self-employment, and demonstrate lesser risk awareness, thus decrease entrepreneurial start-up rates (Carter et al., 2015; Marlow et al., 2012). The disadvantaged position compared to men is also observed in relation to the accumulation of entrepreneurial resources (Jayawarna et al., 2015), education (Carter et al., 1997; Fischer et al., 1993), managerial skills (Zolin et al., 2013), social and professional networks (including socialisation experiences) (Jayawarna et al., 2015), and finance (Freel et al., 2012; Roper and Scott, 2009). Women have been shown to be risk-averse in relation to their business funding strategy (Coleman and Robb, 2012), however, this perspective was challenged with the argument that risk-avoidance among women is a consequence of shifting socio-economic norms, which are reflected in their entrepreneurial endeavors and actions (Marlow and Swail, 2014). In short, belonging to a particular social group (such as female entrepreneurs in the UK) may be marked by the lack of (or diminished) access to human capital, resources and capabilities essential for launching a successful entrepreneurial activity. 
Deprivation of a local area is strongly associated with lower rates of entrepreneurial activity (Devins, 2009; Frankish et al., 2014; Williams and Huggins, 2013; Williams et al., 2017; Williams and Williams, 2017). Human capital is found to be correlated with female entrepreneurship rates (Adom and Asare-Yeboa, 2016; Brush et al., 2017; Caliendo et al., 2014; Marvel et al., 2016). However, these relationships have not been put into the context of a local community, where the mutual effects are disentangled. In other words, it is still not known whether a disadvantaged location further amplifies the disadvantage of a female entrepreneur in terms of involvement into entrepreneurial activity, as intersectionality theory might suggest. Therefore, our theoretical development will examine the impact of gender differences in human capital and deprivation on entrepreneurial activity across local communities.

\section{Human capital and gender differences in entrepreneurial activity}

Human capital theory deals with individual decisions about career choices and investments into skills and knowledge (Becker, 1976). Becker (1994) differentiates two forms of human capital: general and specific human capital. In the context of entrepreneurship, the former refers to the educational qualifications, while the latter refers to having the knowledge, skills and experience to run a new business. Previous research related both forms of human capital with the career choice towards self-employment and entrepreneurship (Davidsson and Honig, 2003; Dimov, 2010; Kim et al., 2006; Passaro et al., 2018), its success (Unger et al., 2011), and exit decisions (Gimeno et al., 1997; Huggins et al., 2017).

A wide range of studies have positively linked human capital dimensions with entrepreneurial activity (see Marvel et al. (2016) for a literature review). The research into general human capital has shown mixed evidence of its effect on entrepreneurial activity. On the one hand, it may not lead to the involvement entrepreneurial activity, as it might be associated with the decreased income in future compared to regular employment (Becker, 1962; Cassar, 2006). On the other hand, evidence also suggests that general human capital increases the likelihood of an individual to engage with entrepreneurial activity through the acquisition of knowledge and skills from education (Davidsson and Honig, 2003; Delmar and Davidsson, 2000; Piperopoulos and Dimov, 2015; Rotefoss and Kolvereid, 2005). Within certain opportunity creation contexts, the availability, and the consequent impact of general human capital might be different (Alvarez and Barney, 2014). Therefore, one could assume that the role of context is particularly important in such a relationship, revealing a gap in 
research on the impact of human capital on entrepreneurial activity beyond the individual level (Marvel et al., 2016).

Research into specific human capital suggests more straightforward findings, where skills and knowledge associated with entrepreneurial context make the individual better equipped to identify and exploit opportunites, and hence are considered to have a positive effect on entrepreneurial activity (Clercq and Arenius, 2006; Corbett, 2007; Ucbasaran et al., 2008). It is also argued that specific human capital is of greater benefit to entrepreneurship (Unger $e t$ $a l ., 2011)$ and is also more likely to be influenced by contextual factors when compared to general human capital (Estrin et al., 2016).

In general, it is argued that female entrepreneurs are disadvantaged compared to their male counterparts in terms of human capital owing to household and societal reasons (Hindle et al., 2009; McGowan et al., 2015). These disparities mainly arise from their limited work experience and its more administrative nature, which hinder the development of enterpising skills and social networks (Carter et al., 2003; Patterson and Mavin, 2009). Therefore, based on social exclusion theory, women are viewed as a disadvantaged group, willing to engage with entrepreneurial activity, but having limited access to human capital and abilities to convert resources into opportunities (Abrams et al., 2008).

When both males and females have the same level of general human capital within a community, they are likely to be equally equipped with a general stock of information and skills, including the ones need to recognise entrepreneurial opportunities in the environment (Marvel et al., 2016). Therefore, it is likely to lead to similar level of entrepreneurship rates across genders within the community. When there are equal levels of specific human capital between males and females within a community, they are likely to express similar perceptions in terms of their knowledge and abilities to run a new venture. The presence of similar levels of specific human capital would imply that females are on an equal footing with men when it comes to entrepreneurship-specific skills like problem-solving, knowledge about markets and knowledge about customers (Shane, 2000). Therefore, it would lead to better identification and exploitation of entrepreneurial opportunities (Marvel, 2013), leading to a similar gender ratio in entrepreneurship rates within the community. Based on the above arguments, we hypothesize that: 
H1: When women in a community have the same level of general human capital as men in that community, they are more likely to have same level of early stage entrepreneurial activity as men.

H2: When women in a community have the same level of specific human capital as men in that community, they are more likely to have same level of early stage entrepreneurial activity as men.

Community deprivation and spatial exclusion

Community deprivation refers to lack of resources within the community, which may be viewed in terms of income, material wealth, educational standards, nutritional levels, and infrastructure (Blackburn and Ram, 2006). A deprived community is likely to be characterized by lack of market opportunities (Storey and Johnson, 1987), poor infrastructure and other support mechanisms (Slack, 2005; Taylor and Plummer, 2003; Welter et al., 2008) needed for entrepreneurship. Therefore, it is acknowledged that deprived areas will have lower levels of entrepreneurial activity (Thompson et al., 2008; Williams and Williams, 2011).

The level of deprivation in an area imposes different roles on women in terms of social expectations regarding family and household (Allen and Truman, 2016). Moreover, higher levels of unemployment in deprived communities result in childcare and household chores being undertaken by women (Metcalf, 2013). As a result, women are less engaged in any type of economic activity compared to men in deprived communities. Furthermore, women tend to perceive the environment in a more negative light than men do (Langowitz and Minniti, 2007) and are more risk averse (Coleman and Robb, 2012), which are likely to negatively affect their entrepreneurial behaviour in deprived areas. In deprived communities, there also exists a greater skew of resource acquisition and market advantages in favor of men (Bates, 2010; Jayawarna et al., 2011; Rouse and Jayawarna, 2011; Williams and Williams, 2011). Hence, women are likely to encounter greater difficulties in identifying and exploiting new business opportunities in deprived communities. Therefore, we hypothesize that:

H3: The higher the level of community deprivation the lower the level of gender differences in early stage entrepreneurial activity at the community level.

The concept of intersectionality suggests that the interaction between a range of discourses further exemplifies a socially-constructed disadvantage leading to exclusion 
(Crenshaw, 1997; Martinez Dy et al., 2014). It is argued that intersectionality of identities drives positionality, which refers to a dynamic position across social structures and agencies (Anthias, 2001), moderating the relationship between social disadvantage and resource allocation (e.g. human capital) (Martinez Dy et al., 2017). Entrepreneurial identity, one of the manifestations of occupational identity, is a mental process through which an individual constructs a reflective image of one's own identity based on individual discourses, such as gender, social class, and ethnicity (Drakopoulou Dodd and Anderson, 2007), as well as environmental conditions (including external influences, societal norms and expectations, and place) (Gill and Larson, 2014). The evolution of such self-constructions will lead to the emergence of a dominant form of entrepreneurial identity in the society. As a result, a rigid perception of the identity of an entrepreneur as a white, urban, male, young/middle-aged individual arises, imposing an additional psychological barrier for individuals not belonging to that identity to overcome (Ashcraft, 2007; Gill and Ganesh, 2007).

The intersectionality perspective meshes well with the mixed embeddedness framework, where individuals are positioned within a social and economic context, which at the level of a community imposes opportunities and challenges for entrepreneurial activity (Dacin et al., 1999; Granovetter, 1985; Jack and Anderson, 2002; Ram et al., 2008). Locallevel factors in combination with individual determinants and wider macroeconomic influences determine the availability of entrepreneurial capital (including human capital) defining access to opportunities (Kloosterman, 2010).

Based on intersectionality theory and mixed embeddedness framework, we can portray women in disadvantaged areas as encountering two discourses: location and gender, which influence their self-identity in relation to a male entrepreneur (Ashcraft, 2007; Drakopoulou Dodd and Anderson, 2007). On the locational front, deprived communities are likely to have limited schooling facilities supporting education. Also, these communities experience low entrepreneurial rates (Hughes et al., 2012), higher unemployment (Bynner and Parsons, 2002), and limited social exposure (Jayawarna et al., 2015). Therefore, individuals from these areas are likely to have lower levels of general and specific human capital. It is acknowledged that deprived areas have lesser availability of entrepreneurial capital to support new ventures (Lee and Cowling, 2013; Rouse and Jayawarna, 2006). On the gender front, entrepreneurial identity for males in disadvantaged communities will be determined by location alone, other things equal. However, women need to take cognizance of the dominant type of entrepreneurial 
identity in the society (illustrated earlier) and locational factors. Considering that the former effect is attributed to women only, and the latter one - to both genders, the position of women in terms of entrepreneurial activity is further aggravated in deprived communities compared to male counterparts. This is likely to hinder women in terms of their aspirations, abilities and access to resources needed to start a new venture. In summary, entrepreneurial identities, social hierarchies and locational disadvantages are likely to curtail both forms of human capital acquistion and utilization by socially disadvantaged sections (Ram et al., 2011) like women towards entrepreneurship leading to a double disadvantage. Therefore, we hypothesize that:

H4a: The level of deprivation within a community negatively moderates the relationship between gender differences in general human capital and gender differences in early stage entrepreneurial activity at the community level.

H4b: The level of deprivation within a community negatively moderates the relationship between gender differences in specific human capital and gender differences in early stage entrepreneurial activity at the community level.

The final conceptual model is presented in Figure 1.

[Insert Figure 1 about here]

\section{Data and methods}

Sample

We combine the Global Entrepreneurship Monitor (GEM) data for United Kingdom with the Index of Multiple Deprivation (IMD) for the period 2007-2012 in this study. We use the GEM Adult Population Survey (APS) for data on individual characteristics and entrepreneurship rates within the adult population. GEM surveys are conducted annually since 2001 and captures information on a wide range of entrepreneurship related factors through face-to-face and telephone interviews (Levie and Autio, 2008). These surveys are considered rich, reliable and valid (Reynolds et al., 2005), and have been extensively used in recent entrepreneurship research (Brush et al., 2017; Estrin et al., 2016).

Index of Multiple Deprivation (IMD) developed and collected by the Office of National Statistics (ONS) is used to capture community deprivation across local areas in the UK. It reflects the socio-economic environment at a community level and is available at the lower layer super output areas (coherent communities of around 1,500 people) across England, and 
similarly defined data zones in Wales, Scotland, and Northern Ireland. The measures of multiple deprivation vary across four home nations in the UK, and combine a different, but similar set of community-level indicators. The indicators are calculated based on Census data and alternative data from administrative sources. The rank-based index allows one to estimate the relative position of a community in terms of deprivation, where a higher deprivation score implies a more deprived area (Noble et al., 2008).

The methodology of IMD calculation across the four home nations is different, making direct comparisons impossible within the UK. Income and employment deprivation domains are measured in the most consistent way, while other dimensions and their construction vary considerably (Department for Communities and Local Government; Northern Ireland Statistics and Research Agency; Stats Wales; The Scottish Government). As a result, the indices were adjusted to make them comparable both across years and home nations.

Following the methodology developed by Payne and Abel (2012), England indices are used as the baseline for the universal score, where a rank correlation coefficient (Kendall's tau) between adjusted and original IMD achieved 0.91 for Wales, 0.96 for Scotland, and 0.97 for Northern Ireland. To construct the adjusted scores, a linear regression model was computed for each home nation, with the overall IMD as the dependent variable, and income and employment domains as independent variables. The results of the modelling for each home nation are presented in Table 1. Next, residuals were obtained using those models, as an estimation of the unique contribution of other domains of deprivation (not income and employment) to the overall IMD. And, finally, the adjusted scores for each country were worked out using the formula proposed by Payne and Abel (2012).

\section{[Insert Table 1 about here]}

Another amendment was made in relation to the time period for which the indicators are calculated. Within the observation period English IMD are available for 2007 and 2010, Welsh ones (WIMD) are there for 2008 and 2011, Scottish (SIMD) - for 2006, 2009, and 2012, and Northern Ireland measures (NIMDM) - for 2010. As a result, two scores were worked out: 1) for the pre-crisis period (IMD for 2007, WIMD for 2008, SIMD for 2006, and NIMDM for 2010); and 2) for the after-crisis period (IMD for 2010, WIMD for 2011, SIMD for 2012, and NIMDM for 2010). The adjusted indices of multiple deprivation both for the pre-crisis and post-crisis periods were merged with the GEM data set according to the following procedure: 
1) Postcodes associated with each individual in the GEM data set were matched with LSOAs (England and Wales), data zones (Scotland), and super output areas (Northern Ireland) through GeoConvert (UK Data Service Census Support);

2) Each LSOA, data zone, and super output area identified was matched with the adjusted IMD for the pre-crisis and post-crisis periods.

As a result, matched IMD were available for 78\% (the mean for the period 2007-2012) of the cases which ensured the representativeness of the sample. In order to address the research question at the community level and to obtain sufficient sample of respondents within the communities, we geographical clustered adjactent LSOAs to create 200 community areas.

\section{Dependent variable}

Our dependent variable is the gender ratio in total early stage entrepreneurial activity (TEA) at the community level. GEM captures this data at the individual level based on whether individuals are nascent ${ }^{1}$ or new $^{2}$ entrepreneurs (Hechavarría and Ingram, 2018). We aggregate this to the community level using the mean value as specified in Table 2.

\section{Independent variables}

General human capital gender ratio and specific human capital gender ratio at the community level are measured as a mean aggregate ratio from the individual level data (refer Table 2). At the individual level, general human capital is operationalized based on whether respondents have post-secondary level educational qualification (Estrin et al., 2016). Individual specific human capital is a perception-based measure of whether individuals believe that they have the skills, knowledge and experience to start a new business (De Clercq et al., 2013). As highlighted earlier, community deprivation was measured using the mean IMD value aggregated at the geographically clustered community level.

\section{Control variables}

Following prior research (Hechavarría and Ingram, 2018; Huggins et al., 2017), we use multiple control variables at the community level. We control for socio-demographic factors like age and household income. We also control for multiple entrepreneurial culture related

\footnotetext{
${ }^{1}$ Nascent entrepreneur - actively involved in start-up effort

${ }^{2}$ New entrepreneur - owner managers of a business that is less than 42 months old
} 
factors at the community level like peer networks with entrepreneurs, media perception of entrepreneurship and status associated with entrepreneurship (refer Table 2 for details). In addition, we control for the stage of the economy (2007: pre-recession stage; 2008-2009: recession stage; 2010-2012: post-recession stage) using dummy variables.

\section{Data analyses and results}

Table 2 summarizes our variables, their operationalization and summary statistics. In Table 3, we present the correlation matrix. From this, we observe that there are no very high correlations between the variables. In our regression models, we further tested for multicollinearity using the VIF statistic and observed that those were within the range of 4 (Cohen et al., 2003; Neter et al., 1996). In addition, we also noted that the overall condition number was less than 15. These suggest that (Belsley et al., 2005) multi-collinearity is not a serious concern in our study.

We performed OLS regression to test our hypotheses. In order to overcome heteroscedasticity concerns in aggregated data, we used robust standard errors in the analyzes. Model 1 presents the results for the control varables. In Models 2, 3 and 4, we include the independent variables general human capital gender ratio, specific human capital gender ratio and community deprivation, respectively. From Model 2, we find support for Hypothesis 1, as we observe a positive and significant relationship between general human capital gender ratio and TEA gender ratio $(\beta=0.03, \mathrm{p}<0.001)$. Similarly, we notice a positive and significant relationship between specific human capital gender ratio and TEA gender ratio $(\beta=0.46, p<$ 0.001 ) in Model 3. This illustrates support for Hypothesis 2. However, in Model 4, we observe a negative and significant effect of community deprivation on TEA gender ratio $(\beta=-0.01, p$ $<0.001$ ), lending support to Hypothesis 3. Models 5 and 6 present the results for interaction between human capital gender ratio variables and community deprivation. We find that community deprivation has a negative and significant moderating effect for both - general human capital gender ratio-TEA gender ratio $(\beta=-0.04, \mathrm{p}<0.001)$ and specific human capital gender ratio-TEA gender ratio $(\beta=-0.16, p<0.001)$ - relationships. This offers support for Hypotheses $4 \mathrm{a}$ and $4 \mathrm{~b}$.

[Insert Tables 2, 3 and 4 about here] 
While testing interaction effects, the direction and statistical significance of the interaction terms are likely to vary for different values of independent variables (Hoetker, 2007; Zelner, 2009). Therefore, it is important to not merely interpret the interaction term by examining the direction, magnitude and statistical significance of the resulting coefficients (Maekelburger et al., 2012). Hence, we plot the interaction effects in Figures 2a and 2b.

[Insert Figures 2a and 2b about here]

\section{Robustness tests}

We conducted multiple robustness checks, which support our findings. Firstly, we conducted the entire analysis replacing TEA gender ratio with entrepreneurial growth aspiration $^{3}$ gender ratio and found similar results. We also utilized an alternative measure for specific human capital composed of individuals' perception of risk, capabilities and social networks (Arenius and Minniti, 2005) and obtained consistent results.

\section{Discussion and conclusions}

Our study contextualizes the relationship between gender ratio in human capital and gender ratio in entrepreneurial activity by focusing on local communities within the UK. Combining the perspectives of human capital, intersectionality and positionality in the mixed embeddness framework, we theorize a double-disadvantage effect faced by female entrepreneurs in deprived communities. Prior research applying the concept of intersectionality at the individual level has informed us of the constructed identity of female entrepreneurs (Martinez Dy et al., 2017; Wang and Warn, 2017). We embed this within communities to explain disproportions in the availability of human capital and associated gender disparities in entrepreneurial activity at a community level coupled with the contingent effect of community deprivation.

\section{Theoretical contributions}

Our results suggest that women are not only disadvantaged in terms of human capital when starting a new business compared to men, but also their situation is worsened by the deprived location, imposing a double disadvantage effect. The disadvantaged position of

\footnotetext{
${ }^{3}$ Expecting to employ at least one more employee in the next 5 years
} 
women in terms of human capital is already well researched in the literature on social exclusion at the individual level (Bernat et al., 2017; Fairlie and Robb, 2007; Thiess et al., 2015). However, our findings embed the relationship between the gender ratio in human capital and the gender ratio in entrepreneurial activity in a community context. The effect of spatial exclusion at the local community level, which exacerbates the impact of social exclusion of women, is the first contribution of our paper to the literature on disadvantaged entrepreneurship.

Secondly, we add to the literature on economy geography by exploring community level effects on entrepreneurship (Ghani et al., 2013; Langevang et al., 2015). Our findings suggest that locational deprivation reassert the disadvantages for the socially excluded (Perucca et al., 2018). We know that deprivation within the UK is highly spatially concentrated and has persisted over time (Rae, 2012). Therefore, the social and spatial disadvantages associated with entrepreneurial activity are also likely to have persisted over time, highlighting the need for immediate policy attention.

Finally, we also make minor contributions to the literature on human capital and entrepreneurship. We already know about the role of human capital on entrepreneurship at the individual (Davidsson and Honig, 2003), firm (Marvel et al., 2016), and country levels (Brush et al., 2017). We extend this by studying gender ratio at a community level and identify that communities that have equality in human capital levels across genders are likely to achieve equality in entrepreneurial rates across genders. We also contextualize this effect by highlighting the contingent role of community deprivation.

\section{Policy implications}

There exists a lot of contemporary interest around issues of gender pay differences, both in full or part-time employment (Olsen et al., 2018), and self-employment (Department for Business Innovation and Skills, 2016). This indicates that social exclusion of women is still persistent despite governmental efforts to address inequality by offering support to female entrepreneurs to fill gaps in their human capital acquisition. Local enterprise growth initiative attempted to tackle deprivation through encouraging entrepreneurial activity in deprived areas by introducing various forms of support, including investments into human capital (Local Government Improvement and Development, 2010; The Baroness Mone OBE, 2016). In this vein, considering the importance of gender disparity and deprivation in the political agenda, 
our results throw light on the compounding effect of social and spatial exclusion. Our findings suggest that the gender ratio in entrepreneurial activity is affected by the deprivation level of a local area, which further constraints the availability and utilization of both general and specific human capital by women towards entrepreneurship. Therefore, it is not merely the availability of local support schemes that matters in addressing this issue, but the consideration of a broader social context (Jayawarna et al., 2015; Marlow and Swail, 2014), where the social role of women, societal expectations, and other pressures of deprived areas hinder the prospects of gender equality in entrepreneurial activity.

\section{Limitations and Future Research}

There are two main limitations associated with the study. The first one relates to the operationalization issues arising from the nature of the dataset. The categorization of general and specific human capital is limited to the variables available in the GEM dataset across local communities. Human capital measures could encompass a broader range of parameters, reflecting a richer definition adopted in selected studies (Martin et al., 2013; Marvel et al., 2016). For instance, certain dimensions of task-specific and general human capital like the type of formal education, entrepreneurial training, participation in local mentoring skills (Marvel et $a l ., 2016)$ may be used in future research for developing a more fine-grained understanding.

The second limitation refers to the contextualization aspect. Although satisfying the pursued research objective by relying on a multidimensional construct of multiple deprivation, future studies could consider each deprivation domain (income, employment, education, health, living environment, housing, and crime) separately. Future research may also include other measures to characterize the availability of social capital (Kang and Snell, 2009) and local support infrastructure (McKeever et al., 2015; Santos et al., 2016). In addition, individual and community level discourses could be analysed within the mixed embeddeddness perspective by disantangling complexities in the interaction of different-level factors (Romero and Valdez, 2016; Wang and Warn, 2017). This would offer scope for multilevel analysis to explain different inclination towards entrepreneurial activity between men and women. It would also be interesting to replicate this study in an emerging market context where the role of gender and institutional characteristics on entrepreneurship are observed to be different from developed markets (Chatterjee and Sahasranamam, 2018; Ghani et al., 2013; Sahasranamam and Sud, 2016). Moreover, future research could adopt a qualitative understanding of human 
capital (Dimov, 2017), wherein a typology of female entrepreneurs could be derived based on their human capital and contextual parameters by means of fuzzy-set methodology. 


\section{References}

Abrams, D., Christian, J., and Gordon, D. 2008. Multidisciplinary handbook of social exclusion research: John Wiley \& Sons.

Adom, K., and Asare-Yeboa, I. T. 2016. "An evaluation of human capital theory and female entrepreneurship in sub-Sahara Africa: Some evidence from Ghana". International Journal of Gender and Entrepreneurship, 8(4): 402-423.

Allen, S., and Truman, C. 2016. Women in business: Perspectives on women entrepreneurs. London: Routledge.

Alvarez, S. A., and Barney, J. B. 2014. "Entrepreneurial opportunities and poverty alleviation". Entrepreneurship Theory and Practice, 38(1): 159-184.

Anthias, F. 2001. "The material and the symbolic in theorizing social stratification: issues of gender, ethnicity and class". The British Journal of Sociology, 52(3): 367-390.

Arenius, P., and Minniti, M. 2005. "Perceptual variables and nascent entrepreneurship". Small Business Economics, 24(3): 233-247.

Ashcraft, K. L. 2007. "Appreciating the 'work'of discourse: Occupational identity and difference as organizing mechanisms in the case of commercial airline pilots". Discourse \& Communication, 1(1): 9-36.

Bates, T. 2010. "Alleviating the financial capital barriers impeding business development in inner cities". Journal of the American Planning Association, 76(3): 349-362.

Becker, G. S. 1962. "Investment in human capital: A theoretical analysis". The Journal of Political Economy, 70(5): 9-49.

Becker, G. S. 1994. "Human capital revisited", Human Capital: A Theoretical and Empirical Analysis with Special Reference to Education (3rd Edition): 15-28: The University of Chicago Press.

Becker, S. G. 1976. The Economic Approach to Human Behaviour. Chicago and London: The University of Chicago Press.

Belsley, D. A., Kuh, E., and Welsch, R. E. 2005. Regression diagnostics: Identifying influential data and sources of collinearity. New York: John Wiley \& Sons.

Bernat, L. F., Lambardi, G., and Palacios, P. 2017. "Determinants of the entrepreneurial gender gap in Latin America". Small Business Economics, 48(3): 727-752.

Blackburn, R., and Ram, M. 2006. "Fix or fixation? The contributions and limitations of entrepreneurship and small firms to combating social exclusion". Entrepreneurship and Regional Development, 18(1): 73-89. 
Brush, C., Ali, A., Kelley, D., and Greene, P. 2017. "The influence of human capital factors and context on women's entrepreneurship: Which matters more?". Journal of Business Venturing Insights, 8: 105-113.

Bynner, J., and Parsons, S. 2002. "Social exclusion and the transition from school to work: The case of young people not in education, employment, or training (NEET)". Journal of Vocational Behavior, 60(2): 289-309.

Caliendo, M., Fossen, F. M., Kritikos, A., and Wetter, M. 2014. "The gender gap in entrepreneurship: Not just a matter of personality". CESifo Economic Studies, 61(1): 202-238.

Carter, N., Brush, C., Greene, P., Gatewood, E., and Hart, M. 2003. "Women entrepreneurs who break through to equity financing: the influence of human, social and financial capital". Venture Capital: An International Journal of Entrepreneurial Finance, 5(1): 1369-1066.

Carter, N. M., Williams, M., and Reynolds, P. D. 1997. "Discontinuance among new firms in retail: The influence of initial resources, strategy, and gender". Journal of Business Venturing, 12(2): 125-145.

Carter, S., Mwaura, S., Ram, M., Trehan, K., and Jones, T. 2015. "Barriers to ethnic minority and women's enterprise: Existing evidence, policy tensions and unsettled questions". International Small Business Journal, 33(1): 49-69.

Carter, S., Ram, M., Trehan, K., and Jones, T. 2013. Diversity and SMEs: Existing Evidence and Policy Tensions, Enterprise Research Centre White Paper, Vol. 3: Warwick Business School.

Cassar, G. 2006. "Entrepreneur opportunity costs and intended venture growth". Journal of Business Venturing, 21(5): 610-632.

Chatterjee, D., and Sahasranamam, S. 2018. "Technological innovation research in China and India: A bibliometric analysis for the period 1991-2015". Management and Organization Review, 14(1): 179-221.

Clercq, D. D., and Arenius, P. 2006. "The role of knowledge in business start-up activity". International Small Business Journal, 24(4): 339-358.

Cohen, J., Cohen, P., West, S. G., and Aiken, L. S. 2003. Applied multiple regression/correlation analysis for the behavioral sciences (3rd ed.). New Jersey: Routledge.

Coleman, J. S., and Robb, A. 2012. A Rising Tide: Financing Strategies for Women Owned Firms. Stanford, CA: Stanford University Press. 
Cooney, T. M. 2012. "Reducing recidivism through entrepreneurship programmes in prisons". The International Journal of Entrepreneurship and Innovation, 13(2): 125133.

Corbett, A. C. 2007. "Learning asymmetries and the discovery of entrepreneurial opportunities". Journal of Business Venturing, 22(1): 97-118.

Crenshaw, K. 1997. "Intersectionality and identity politics: Learning from violence against women

of colour". In M. L. Shanley, \& N. U. (Eds.), Reconstructing Political Theory: 178-193. Oxford: Polity Press.

Curran, J., and Blackburn, R. A. 2001. "Older people and the enterprise society: Age and self-employment propensities". Work, Employment and Society, 15(4): 889-902.

Dacin, M. T., Ventresca, M. J., and Beal, B. D. 1999. "The embeddedness of organizations: Dialogue \& directions". Journal of Management, 25(3): 317-356.

Davidsson, P., and Honig, B. 2003. "The role of social and human capital among nascent entrepreneurs". Journal of Business Venturing, 18(3): 301-331.

De Clercq, D., Honig, B., and Martin, B. 2013. "The roles of learning orientation and passion for work in the formation of entrepreneurial intention". International Small Business Journal, 31(6): 652-676.

Delmar, F., and Davidsson, P. 2000. "Where do they come from? Prevalence and characteristics of nascent entrepreneurs". Entrepreneurship \& Regional Development, 12(1): $1-23$.

Department for Business Innovation and Skills. 2016. The income of the self-employed.

Department for Communities and Local Government. English Indices of Deprivation.

Devins, D. 2009. "Enterprise in deprived areas: what role for start-ups?". International Journal of Entrepreneurship and Small Business, 8(4): 486-498.

Dimic, N., and Orlov, V. 2014. "Entrepreneurial tendencies among people with ADHD". International Review of Entrepreneurship, 13(3): 187-204.

Dimov, D. 2010. "Nascent entrepreneurs and venture emergence: Opportunity confidence, human capital, and early planning". Journal of Management Studies, 47(6): 11231153.

Dimov, D. 2017. "Towards a qualitative understanding of human capital in entrepreneurship research". International Journal of Entrepreneurial Behavior \& Research, 23(2): 210227. 
Dodd, S. D., and Keles, J. 2014. Expanding the networks of disadvantaged entrepreneurs: OECD Technical Report. OECD Local Economic and Employment Development Programme.

Drakopoulou Dodd, S., and Anderson, A. R. 2007. "Mumpsimus and the mything of the individualistic entrepreneur". International Small Business Journal, 25(4): 341-360.

Dubrow, J. K. 2008. "How can we account for intersectionality in quantitative analysis of survey data? Empirical illustration for Central and Eastern Europe". ASK: Society, Research, Methods, 17: 85-102.

Estrin, S., Mickiewicz, T., and Stephan, U. 2016. "Human capital in social and commercial entrepreneurship". Journal of Business Venturing, 31(4): 449-467.

Fairlie, R. W., and Robb, A. 2007. "Families, human capital, and small business: Evidence from the characteristics of business owners survey". ILR Review, 60(2): 225-245.

Fischer, E. M., Reuber, A. R., and Dyke, L. S. 1993. "A theoretical overview and extension of research on sex, gender, and entrepreneurship". Journal of Business Venturing, 8(2): 151-168.

Frankish, J. S., Roberts, R. G., Coad, A., and Storey, D. J. 2014. "Is entrepreneurship a route out of deprivation?". Regional Studies, 48(6): 1090-1107.

Freel, M., Carter, S., Tagg, S., and Mason, C. 2012. "The latent demand for bank debt: characterizing “discouraged borrowers”". Small Business Economics, 38(4): 399-418.

Ghani, E., Kerr, W. R., and O'connell, S. D. 2013. "Local industrial structures and female entrepreneurship in India". Journal of Economic Geography, 13(6): 929-964.

Gill, R., and Ganesh, S. 2007. "Empowerment, constraint, and the entrepreneurial self: A study of white women entrepreneurs". Journal of Applied Communication Research, 35(3): 268-293.

Gill, R., and Larson, G. S. 2014. "Making the ideal (local) entrepreneur: Place and the regional development of high-tech entrepreneurial identity". Human Relations, 67(5): 519-542.

Gimeno, J., Folta, T. B., Cooper, A. C., and Woo, C. Y. 1997. "Survival of the fittest? Entrepreneurial human capital and the persistence of underperforming firms". Administrative Science Quarterly: 750-783.

Granovetter, M. 1985. "Economic action and social structure: the problem of embeddedness". American Journal of Sociology, 91(3): 481-510. 
Hechavarría, D. M., and Ingram, A. E. 2018. "Entrepreneurial ecosystem conditions and gendered national-level entrepreneurial activity: a 14-year panel study of GEM". Small Business Economics: 1-28.

Henry, C., Foss, L., and Ahl, H. 2016. "Gender and entrepreneurship research: A review of methodological approaches". International Small Business Journal, 34(3): 217-241.

Hindle, K., Klyver, K., and Jennings, D. F. 2009. "An "informed" intent model: Incorporating human capital, social capital, and gender variables into the theoretical model of entrepreneurial intentions", Understanding the Entrepreneurial Mind: 3550: Springer.

Hoetker, G. 2007. "The use of logit and probit models in strategic management research: Critical issues". Strategic Management Journal, 28(4): 331-343.

Huggins, R., Prokop, D., and Thompson, P. 2017. "Entrepreneurship and the determinants of firm survival within regions: human capital, growth motivation and locational conditions". Entrepreneurship \& Regional Development, 29(3-4): 357-389.

Hughes, K. D., Jennings, J. E., Brush, C., Carter, S., and Welter, F. 2012. "Extending women's entrepreneurship research in new directions". Entrepreneurship Theory and Practice, 36(3): 429-442.

Jack, S. L., and Anderson, A. R. 2002. "The effects of embeddedness on the entrepreneurial process". Journal of Business Venturing, 17(5): 467-487.

Jayawarna, D., Jones, O., and Macpherson, A. 2011. "New business creation and regional development: Enhancing resource acquisition in areas of social deprivation". Entrepreneurship \& Regional Development, 23(9-10): 735-761.

Jayawarna, D., Jones, O., and Marlow, S. 2015. "The influence of gender upon social networks and bootstrapping behaviours". Scandinavian Journal of Management, 31(3): 316-329.

Jones, T., Ram, M., Edwards, P., Kiselinchev, A., and Muchenje, L. 2014. "Mixed embeddedness and new migrant enterprise in the UK". Entrepreneurship \& Regional Development, 26(5-6): 500-520.

Kang, S. C., and Snell, S. A. 2009. "Intellectual capital architectures and ambidextrous learning: a framework for human resource management". Journal of Management Studies, 46(1): 65-92.

Khan, S., Combaz, E., and McAslan Fraser, E. 2015. Social exclusion: topic guide, Revised Edition ed. Birmingham, UK: GSDRC, University of Birmingham. 
Kim, P. H., Aldrich, H. E., and Keister, L. A. 2006. "Access (not) denied: The impact of financial, human, and cultural capital on entrepreneurial entryin the United States". Small Business Economics, 27(1): 5-22.

Kloosterman, R. C. 2010. "Matching opportunities with resources: A framework for analysing (migrant) entrepreneurship from a mixed embeddedness perspective". Entrepreneurship and Regional Development, 22(1): 25-45.

Kon, Y., and Storey, D. J. 2003. "A theory of discouraged borrowers". Small Business Economics, 21(1): 37-49.

Kushnirovich, N., Heilbrunn, S., and Davidovich, L. 2017. "Diversity of entrepreneurial perceptions: immigrants vs. native population". European Management Review.

Langevang, T., Gough, K. V., Yankson, P. W., Owusu, G., and Osei, R. 2015. "Bounded entrepreneurial vitality: The mixed embeddedness of female entrepreneurship". Economic Geography, 91(4): 449-473.

Langowitz, N., and Minniti, M. 2007. "The entrepreneurial propensity of women". Entrepreneurship Theory and Practice, 31(3): 341-364.

Lee, N., and Cowling, M. 2013. "Place, sorting effects and barriers to enterprise in deprived areas: Different problems or different firms?". International Small Business Journal, 31(8): 914-937.

Levie, J., and Autio, E. 2008. "A theoretical grounding and test of the GEM model". Small Business Economics, 31(3): 235-263.

Local Government Improvement and Development. 2010. Supporting enterprise growth in deprived areas: A good practice guide for councils and local enterprise partnerships.

Maekelburger, B., Schwens, C., and Kabst, R. 2012. "Asset specificity and foreign market entry mode choice of small and medium-sized enterprises: The moderating influence of knowledge safeguards and institutional safeguards". Journal of International Business Studies, 43(5): 458-476.

Marlow, S., Hart, M., Levie, J., and Shamsul, M. K. 2012. Women in enterprise: a different perspective: RBS Group.

Marlow, S., and Patton, D. 2005. "All credit to men? Entrepreneurship, finance, and gender". Entrepreneurship Theory and Practice, 29(6): 717-735.

Marlow, S., and Swail, J. 2014. "Gender, risk and finance: why can't a woman be more like a man?". Entrepreneurship \& Regional Development, 26(1-2): 80-96. 
Martin, B. C., McNally, J. J., and Kay, M. J. 2013. "Examining the formation of human capital in entrepreneurship: A meta-analysis of entrepreneurship education outcomes". Journal of Business Venturing, 28(2): 211-224.

Martinez Dy, A., Marlow, S., and Martin, L. 2017. "A Web of opportunity or the same old story? Women digital entrepreneurs and intersectionality theory". Human Relations, 70(3): 286-311.

Martinez Dy, A., Martin, L., and Marlow, S. 2014. "Developing a critical realist positional approach to intersectionality". Journal of Critical Realism, 13(5): 447-466.

Marvel, M. R. 2013. "Human capital and search-based discovery: A study of high-tech entrepreneurship". Entrepreneurship Theory and Practice, 37(2): 403-419.

Marvel, M. R., Davis, J. L., and Sproul, C. R. 2016. "Human capital and entrepreneurship research: A critical review and future directions". Entrepreneurship Theory and Practice, 40(3): 599-626.

McGowan, P., Cooper, S., Durkin, M., and O'Kane, C. 2015. "The influence of social and human capital in developing young women as entrepreneurial business leaders". Journal of Small Business Management, 53(3): 645-661.

McKeever, E., Jack, S., and Anderson, A. 2015. "Embedded entrepreneurship in the creative re-construction of place". Journal of Business Venturing, 30(1): 50-65.

Metcalf, H. 2013. "Hidden unemployment and the labour market", Understanding unemployment: 173-193: Routledge.

Naudé, W., Gries, T., Wood, E., and Meintjies, A. 2008. "Regional determinants of entrepreneurial start-ups in a developing country". Entrepreneurship and Regional Development, 20(2): 111-124.

Neter, J., Kutner, M. H., Nachtsheim, C. J., and Wasserman, W. 1996. Applied linear statistical models (4th ed.). Boston: Irwin.

Noble, M., McLennan, D., Wilkinson, K., Whitworth, A., Barnes, H., and Dibben, C. 2008. The English Indices of Deprivation. London: Communities and Local Government.

Northern Ireland Statistics and Research Agency. Northern Irelnad Multiple Deprivation Measure.

Olsen, W., Gash, V., Kim, S., and Zhang, M. 2018. The gender pay gap in the UK: evidence from the UKHLS: Government Equalities Office. 
Passaro, R., Quinto, I., and Thomas, A. 2018. "The impact of higher education on entrepreneurial intention and human capital". Journal of Intellectual Capital, 19(1): 135-156.

Patterson, N., and Mavin, S. 2009. "Women entrepreneurs: Jumping the corporate ship and gaining new wings". International Small Business Journal, 27(2): 173-192.

Payne, R. A., and Abel, G. A. 2012. "UK indices of multiple deprivation-a way to make comparisons across constituent countries easier". Health Statistics Quarterly(53): 2237.

Perucca, G., Piacenza, M., and Turati, G. 2018. "Spatial inequality in access to healthcare: evidence from an Italian Alpine region". Regional Studies: 1-12.

Piperopoulos, P., and Dimov, D. 2015. "Burst bubbles or build steam? Entrepreneurship education, entrepreneurial self-efficacy, and entrepreneurial intentions". Journal of Small Business Management, 53(4): 970-985.

Rae, A. 2012. "Spatially concentrated deprivation in England: An empirical assessment". Regional Studies, 46(9): 1183-1199.

Ram, M., Jones, T., Edwards, P., Kiselinchev, A., Muchenje, L., and Woldesenbet, K. 2013. "Engaging with super-diversity: New migrant businesses and the researchpolicy nexus". International Small Business Journal, 31(4): 337-356.

Ram, M., Theodorakopoulos, N., and Jones, T. 2008. "Forms of capital, mixed embeddedness and Somali enterprise". Work, Employment and Society, 22(3): $427-$ 446.

Ram, M., Woldesenbet, K., and Jones, T. 2011. "Raising the 'table stakes'? Ethnic minority businesses and supply chain relationships". Work, Employment \& Society, 25(2): 309-326.

Reynolds, P., Bosma, N., Autio, E., Hunt, S., De Bono, N., Servais, I., Lopez-Garcia, P., and Chin, N. 2005. "Global entrepreneurship monitor: Data collection design and implementation 1998-2003". Small Business Economics, 24(3): 205-231.

Romero, M., and Valdez, Z. 2016. "Introduction to the special issue: Intersectionality and entrepreneurship". Ethnic and Racial Studies, 39(9): 1553-1565.

Roper, S., and Scott, J. M. 2009. "Perceived financial barriers and the start-up decision an econometric analysis of gender differences using GEM data". International Small Business Journal, 27(2): 149-171. 
Rotefoss, B., and Kolvereid, L. 2005. "Aspiring, nascent and fledgling entrepreneurs: An investigation of the business start-up process". Entrepreneurship \& Regional Development, 17(2): 109-127.

Rouse, J., and Jayawarna, D. 2006. "The financing of disadvantaged entrepreneurs: are enterprise programmes overcoming the finance gap?". International Journal of Entrepreneurial Behavior \& Research, 12(6): 388-400.

Rouse, J., and Jayawarna, D. 2011. "Structures of exclusion from enterprise finance". Environment and Planning-Part C, 29(4): 659-676.

Sahasranamam, S., and Sud, M. 2016. "Opportunity and necessity entrepreneurship: A comparative study of India and China". Academy of Entrepreneurship Journal, 22(1): 21.

Santos, F. J., Roomi, M. A., and Liñán, F. 2016. "About gender differences and the social environment in the development of entrepreneurial intentions". Journal of Small Business Management, 54(1): 49-66.

Shane, S. 2000. "Prior knowledge and the discovery of entrepreneurial opportunities". Organization Science, 11(4): 448-469.

Slack, J. 2005. "The new entrepreneur scholarships: self-employment as a means to tackle social deprivation". Education + Training, 47(6): 447-455.

Stats Wales. Welsh Index of Multiple Deprivation.

Storey, D. J., and Johnson, S. 1987. "Regional variations in entrepreneurship in the UK". Scottish Journal of Political Economy, 34(2): 161-173.

Taylor, M., and Plummer, P. 2003. "Promoting local economic growth: the role of entrepreneurship and human capital". Education+ Training, 45(8/9): 558-563.

The Baroness Mone OBE. 2016. Boosting enterprise in more deprived communities.

The Scottish Government. Scottish Index of Multiple Deprivation.

Thiess, D., Vogel, P. M., Grichnik, D., and Brinckmann, J. 2015. Is More Always Better? Re-Assessing the Role of Human Capital in Entrepreneurship. Paper presented at the Academy of Management Proceedings.

Thompson, P., Jones-Evans, D., and Kwong, C. 2008. "Entrepreneurship and the Domains of Deprivation in Wales". Regional Studies Association International on Regions: The Dilemmas of Integration and Competition, Prague: 27-29.

Ucbasaran, D., Westhead, P., and Wright, M. 2008. "Opportunity identification and pursuit: does an entrepreneur's human capital matter?". Small Business Economics, 30(2): 153-173. 
UK Data Service Census Support. GeoConvert.

UK Women's Enterprise Taskforce. 2012. Greater Return on Women's Enterprise.

Unger, J. M., Rauch, A., Frese, M., and Rosenbusch, N. 2011. "Human capital and entrepreneurial success: A meta-analytical review". Journal of Business Venturing, 26(3): 341-358.

Wang, Y., and Warn, J. 2017. "Chinese immigrant entrepreneurship: Embeddedness and the interaction of resources with the wider social and economic and context". International Small Business Journal: 131-148.

Welter, F., Trettin, L., and Neumann, U. 2008. "Fostering entrepreneurship in distressed urban neighbourhoods". International Entrepreneurship and Management Journal, 4(2): 109-128.

Williams, N., and Huggins, R. 2013. "Supporting entrepreneurship in deprived communities: a vision too far?". Journal of Small Business and Enterprise Development, 20(1): 165-180.

Williams, N., Huggins, R., and Thompson, P. 2017. "Entrepreneurship and Social Capital: Examining the Association in Deprived Urban Neighbourhoods". International Journal of Urban and Regional Research.

Williams, N., and Williams, C. 2017. "2. Entrepreneurship and deprived urban areas: understanding activity and the hidden enterprise culture". Entrepreneurial Neighbourhoods: 21.

Williams, N., and Williams, C. C. 2011 . "Tackling barriers to entrepreneurship in a deprived urban neighbourhood". Local Economy, 26(1): 30-42.

Zelner, B. A. 2009. "Using simulation to interpret results from logit, probit, and other nonlinear models". Strategic Management Journal, 30(12): 1335-1348.

Zolin, R., Stuetzer, M., and Watson, J. 2013. "Challenging the female underperformance hypothesis". International Journal of Gender and Entrepreneurship, 5(2): 116-129. 
Figure 1 Conceptual model

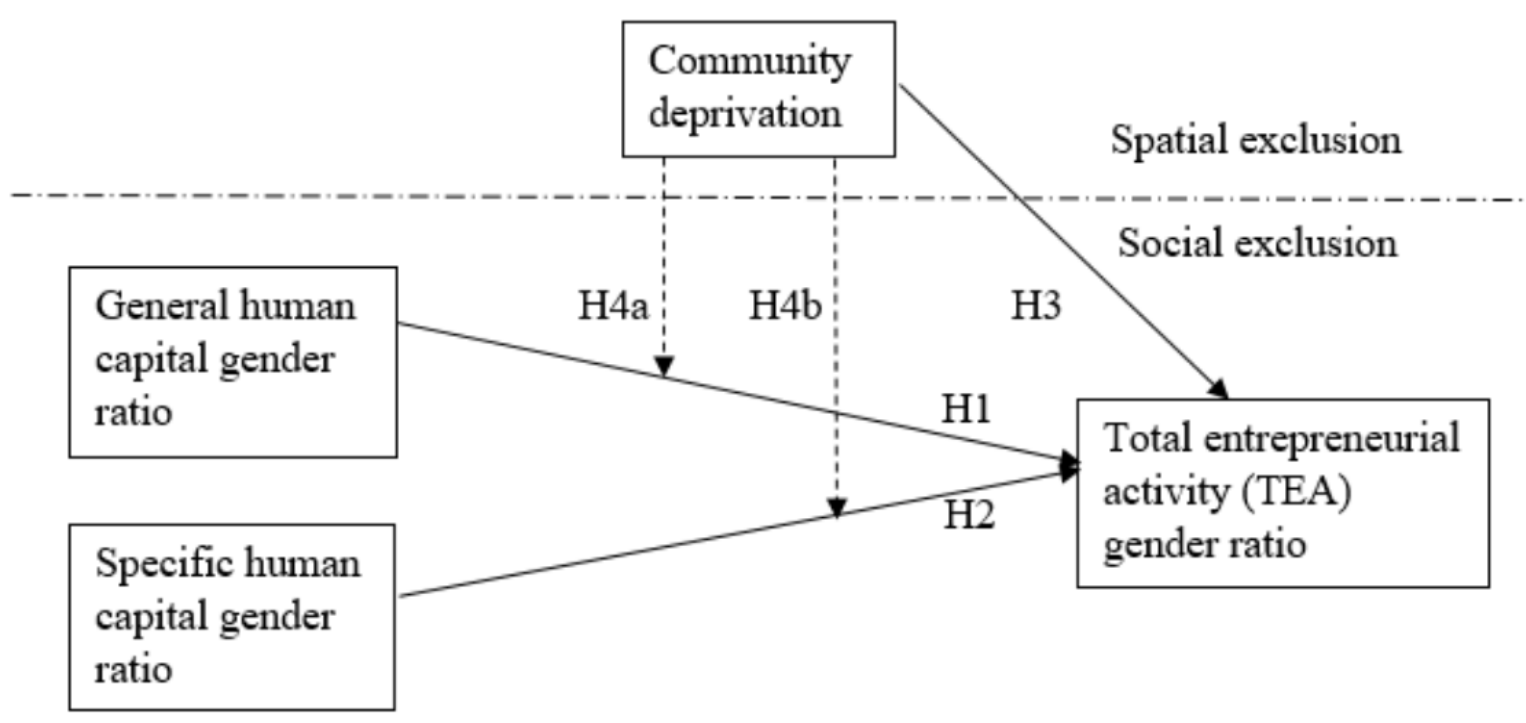


Table 1 Estimations of the regression models for the Indices of Multiple Deprivation in England, Scotland, Wales, and Northern Ireland.

\begin{tabular}{|c|c|c|c|c|c|c|c|}
\hline & \multicolumn{2}{|c|}{ England } & \multicolumn{2}{|c|}{ Scotland } & \multicolumn{2}{|c|}{ Wales } & \multirow{2}{*}{$\begin{array}{c}\text { Northern } \\
\text { Ireland } \\
2010\end{array}$} \\
\hline & 2007 & 2010 & 2006 & 2012 & 2008 & 2011 & \\
\hline Constant & -0.50 & -0.19 & -0.79 & -1.62 & 6.02 & 5.42 & -6.60 \\
\hline Income Domain coefficient & 0.71 & 0.85 & 0.89 & 0.89 & 0.46 & 0.27 & 0.72 \\
\hline $\begin{array}{l}\text { Employment Domain } \\
\text { coefficient }\end{array}$ & 1.09 & 0.93 & 0.76 & 0.83 & 0.26 & 0.48 & 0.76 \\
\hline $\begin{array}{l}\text { Estimated standard deviation } \\
\text { of the residuals }\end{array}$ & 3.52 & 3.59 & 2.73 & 3.09 & 3.19 & 2.77 & 2.86 \\
\hline Number of observations & \multicolumn{2}{|c|}{32481} & \multicolumn{2}{|c|}{6504} & \multicolumn{2}{|c|}{1895} & 889 \\
\hline
\end{tabular}


Table 2 Variable operationalization and summary statistics

\begin{tabular}{|c|c|c|c|}
\hline Variable & Operationalization & Mean & s.d. \\
\hline \multicolumn{4}{|l|}{$\begin{array}{l}\text { Dependent } \\
\text { variable }\end{array}$} \\
\hline $\begin{array}{l}\text { Total } \\
\text { entrepreneurial } \\
\text { activity gender } \\
\text { ratio (TEA gender } \\
\text { ratio) }\end{array}$ & $\begin{array}{l}\text { Ratio of female total early-stage entrepreneurial } \\
\text { activity (TEA) rate over male TEA rate among } \\
18-64 \text { year old adult population at the community } \\
\text { level }\end{array}$ & 0.50 & 0.21 \\
\hline \multicolumn{4}{|l|}{$\begin{array}{l}\text { Independent } \\
\text { variables }\end{array}$} \\
\hline $\begin{array}{l}\text { General human } \\
\text { capital gender } \\
\text { ratio }\end{array}$ & $\begin{array}{l}\text { Ratio of female post-secondary education } \\
\text { completion rate over male rate among } 18-64 \text { year } \\
\text { old adult population at the community level }\end{array}$ & 1.43 & 0.31 \\
\hline $\begin{array}{l}\text { Specific human } \\
\text { capital gender } \\
\text { ratio }\end{array}$ & $\begin{array}{l}\text { Ratio of female entrepreneurial specific } \\
\text { knowledge perception rate over male rate among } \\
18-64 \text { year old adult population at the community } \\
\text { level }\end{array}$ & 0.85 & 0.12 \\
\hline $\begin{array}{l}\text { Community } \\
\text { deprivation } \\
\text { Control variables }\end{array}$ & Index of Multiple Deprivation & 26.22 & 11.59 \\
\hline Age & Mean age of respondents at the community level & 45.05 & 1.31 \\
\hline $\begin{array}{l}\text { Peer networks } \\
\text { with entrepreneurs }\end{array}$ & $\begin{array}{l}\text { Mean value of individuals knowing other } \\
\text { entrepreneurs at the community level }\end{array}$ & 0.26 & 0.03 \\
\hline Household income & $\begin{array}{l}\text { Mean value of household income at the } \\
\text { community level }\end{array}$ & 3.37 & 0.23 \\
\hline $\begin{array}{l}\text { Media perception } \\
\text { of } \\
\text { entrepreneurship }\end{array}$ & $\begin{array}{l}\text { Mean value of individual perception of media } \\
\text { support for entrepreneurship at the community } \\
\text { level }\end{array}$ & 0.51 & 0.03 \\
\hline $\begin{array}{l}\text { Status associated } \\
\text { with } \\
\text { entrepreneurship }\end{array}$ & $\begin{array}{l}\text { Mean value of individual perception of status } \\
\text { associated with entrepreneurship at the } \\
\text { community level }\end{array}$ & 0.72 & 0.03 \\
\hline
\end{tabular}


Table 3 Correlation matrix

\begin{tabular}{|c|c|c|c|c|c|c|c|c|c|}
\hline Variables & 1 & 2 & 3 & 4 & 5 & 6 & 7 & 8 & 9 \\
\hline TEA gender ratio & 1 & & & & & & & & \\
\hline General human capital gender ratio & -0.00 & 1 & & & & & & & \\
\hline Specific human capital gender ratio & $0.30 *$ & $0.33 *$ & 1 & & & & & & \\
\hline Community deprivation & $-0.19 *$ & $0.12 *$ & $-0.16^{*}$ & 1 & & & & & \\
\hline Age & $0.26^{*}$ & $0.07 *$ & $0.19 *$ & $-0.22 *$ & 1 & & & & \\
\hline Social capital with entrepreneurs & $0.11 *$ & $0.01 *$ & $0.13 *$ & $-0.27 *$ & $-0.06^{*}$ & 1 & & & \\
\hline Household income & $0.17 *$ & $-0.19^{*}$ & $0.02 *$ & $-0.63 *$ & $-0.04 *$ & $0.37 *$ & 1 & & \\
\hline Media support of entrepreneurship & $-0.01 *$ & $0.20 *$ & $0.09 *$ & $-0.12 *$ & $-0.08^{*}$ & $0.12 *$ & $-0.06^{*}$ & 1 & \\
\hline Status associated with entrepreneurship & $-0.27 *$ & $0.21 *$ & $0.01 *$ & $0.16^{*}$ & $-0.38 *$ & $-0.05^{*}$ & $-0.09 *$ & $0.21 *$ & 1 \\
\hline
\end{tabular}

$* \mathrm{p}<0.05$ 
Table 4 Regression results on TEA gender ratio

\begin{tabular}{|c|c|c|c|c|c|c|}
\hline Variables & Model 1 & Model 2 & Model 3 & Model 4 & Model 5 & Model 6 \\
\hline $\begin{array}{l}\text { General human capital } \\
\text { gender ratio (GHC } \\
\text { gender ratio) }\end{array}$ & & $0.03^{* * *}(0.00)$ & & & $0.03^{* * *}(0.00)$ & \\
\hline $\begin{array}{l}\text { Specific human capital } \\
\text { gender ratio (SHC gender } \\
\text { ratio) }\end{array}$ & & & $0.46^{* * *}(0.01)$ & & & $0.45^{* * *}(0.00)$ \\
\hline $\begin{array}{l}\text { Community deprivation } \\
\text { (CD) }\end{array}$ & & & & $-0.01^{* * *}(0.01)$ & $0.05^{* * *}(0.00)$ & $0.13^{* * *}(0.00)$ \\
\hline GHC gender ratio $x \mathrm{CD}$ & & & & & $-0.04^{* * *}(0.00)$ & \\
\hline SHC gender ratio $x \mathrm{CD}$ & & & & & & $-0.16^{* * *}(0.00)$ \\
\hline Age & $0.03^{* * *}(0.00)$ & $0.03^{* * *}(0.00)$ & $0.02^{* * *}(0.00)$ & $0.03^{* * *}(0.00)$ & $0.03^{* * *}(0.00)$ & $0.02^{* * *}(0.00)$ \\
\hline $\begin{array}{l}\text { Social capital with } \\
\text { entrepreneurs }\end{array}$ & $0.38^{* * *}(0.01)$ & $0.36^{* * *}(0.01)$ & $0.13^{* * *}(0.01)$ & $0.35^{* * *}(0.01)$ & $0.34^{* * *}(0.01)$ & $0.10^{* * *}(0.01)$ \\
\hline Household income & $0.13^{* * *}(0.00)$ & $0.14^{* * *}(0.00)$ & $0.13^{* * *}(0.00)$ & $0.11^{* * *}(0.00)$ & $0.11^{* * *}(0.00)$ & $0.12^{* * *}(0.00)$ \\
\hline $\begin{array}{l}\text { Media support of } \\
\text { entrepreneurship }\end{array}$ & $0.30^{* * *}(0.01)$ & $0.26^{* * *}(0.01)$ & $0.18^{* * *}(0.01)$ & $0.26^{* * *}(0.01)$ & $0.23^{* * *}(0.01)$ & $0.14^{* * *}(0.01)$ \\
\hline $\begin{array}{l}\text { Status associated with } \\
\text { entrepreneurship }\end{array}$ & $-1.38^{* * *}(0.02)$ & $-1.46^{* * *}(0.02)$ & $-1.56^{* * *}(0.02)$ & $-1.27^{* * *}(0.02)$ & $-1.38^{* * *}(0.02)$ & $-1.52^{* * *}(0.02)$ \\
\hline \multirow[t]{2}{*}{ Constant } & $-0.72^{* * *}(0.03)$ & $-0.65^{* * *}(0.03)$ & $-0.36^{* * *}(0.03)$ & $-0.79^{* * *}(0.04)$ & $-0.60^{* * *}(0.04)$ & $-0.36^{* * *}(0.04)$ \\
\hline & \multicolumn{6}{|c|}{ Stage of the economy dummies included } \\
\hline R-squared & 0.139 & 0.141 & 0.207 & 0.139 & 0.145 & 0.217 \\
\hline F-stat & $3498.29^{* * *}$ & $3046.26^{* * *}$ & $4186.19^{* * *}$ & $3096.79^{* * *}$ & $2705.13^{* * *}$ & $3415.72^{* * *}$ \\
\hline
\end{tabular}


Figure 2a Interaction effect between community deprivation and general human capital gender ratio (red solid line represents high value of general human capital gender ratio and blue dotted line represents low value of general human capital gender ratio)

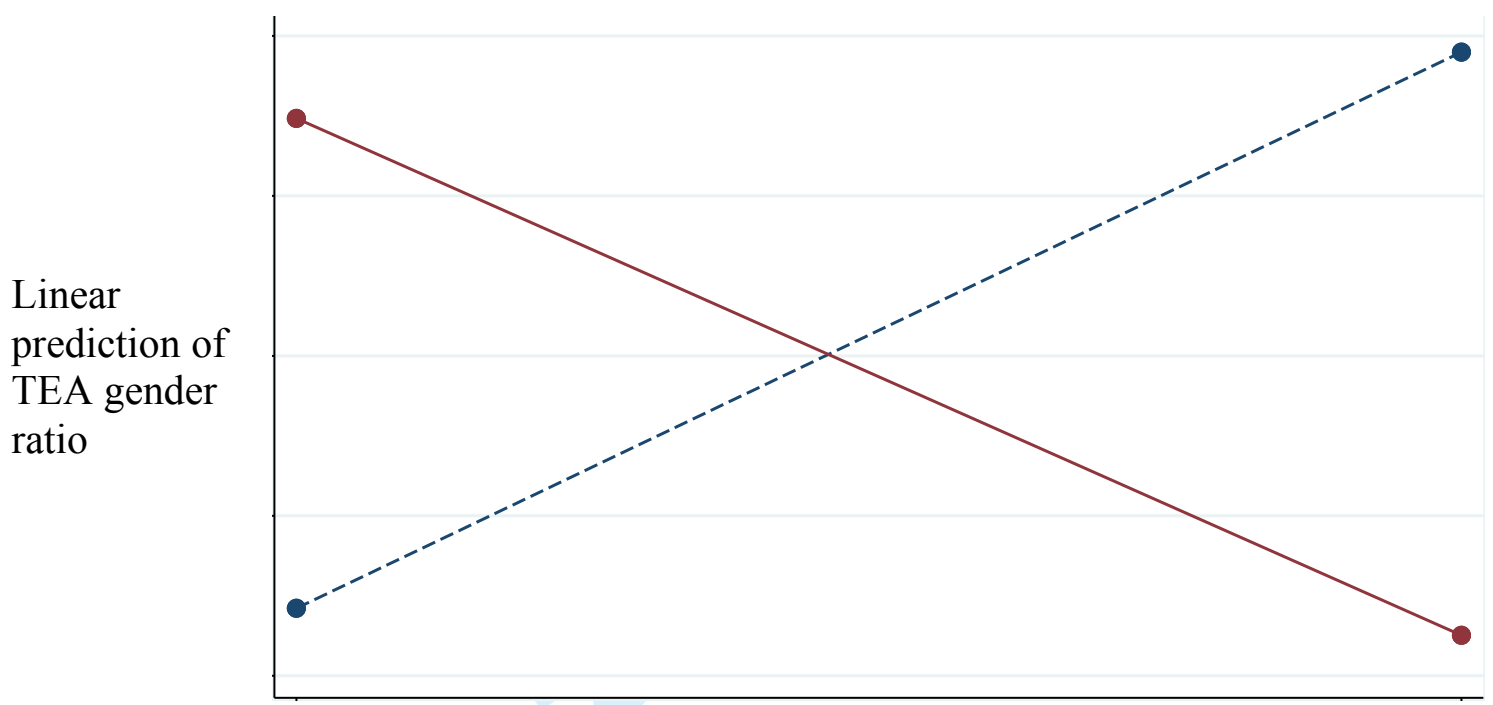

Low deprivation

High deprivation

Figure 2b Interaction effect between community deprivation and specific human capital gender ratio (red solid line represents high value of specific human capital gender ratio and blue dotted line represents low value of specific human capital gender ratio)

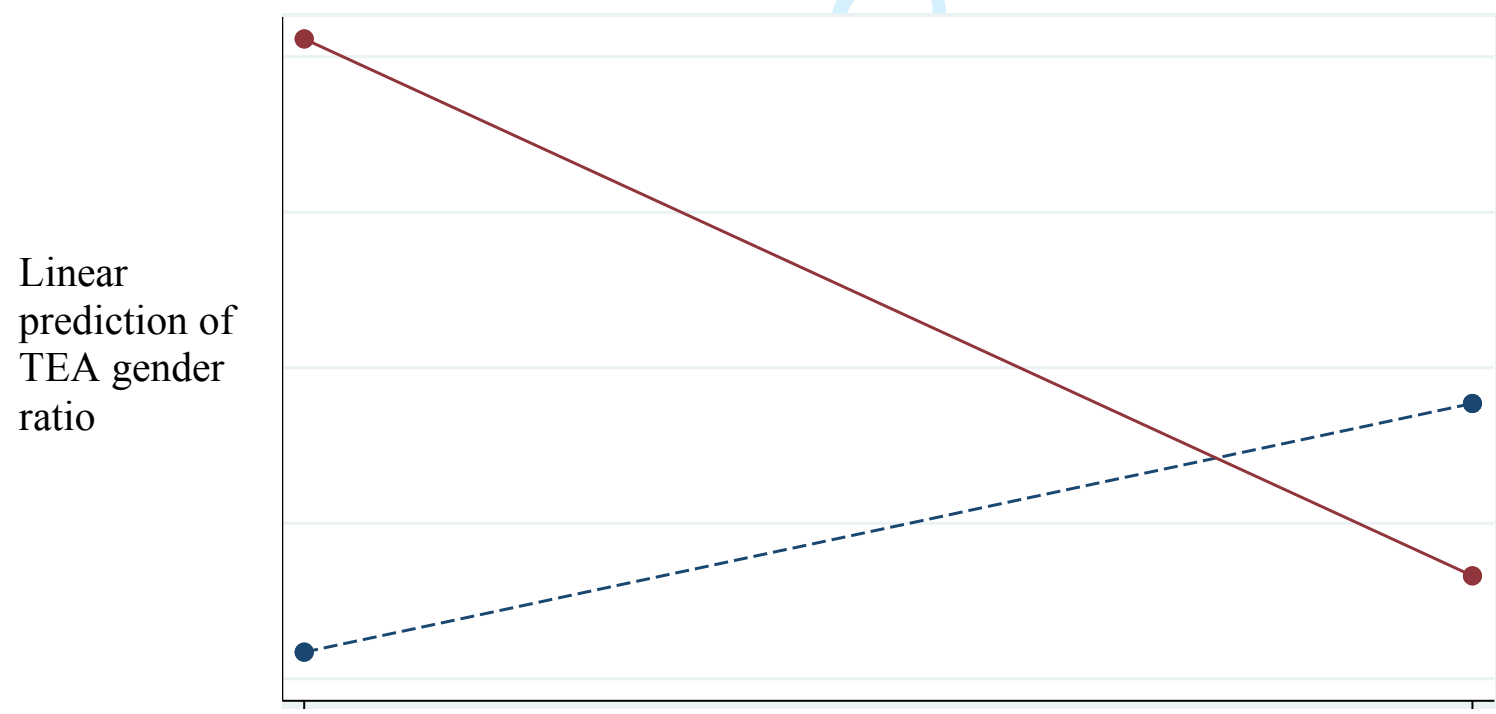

Low deprivation

High deprivation 


\title{
Doubly Disadvantaged: Gender, Spatially Concentrated Deprivation and Nascent Entrepreneurial Activity
}

\begin{abstract}
Drawing on human capital, intersectionality and mixed embeddedness theory, we test hypotheses on the relationship between gender differences in human capital and gender differences in nascent entrepreneurial activity across geographical space, and the moderating effect of spatially concentrated deprivation on this relationship. Using UK data from Global Entrepreneurship Monitor, we find that the disadvantaged position of female nascent entrepreneurs arises from social exclusion, and specifically that the gender differences in nascent entrepreneurial activity are directly related to differences in general and specific human capital across locales. Moreover, in deprived locations, women as a group do not gain from any human capital advantage they might have over men, causing a double disadvantage for women. Our results make a novel contribution to the literature on disadvantage entrepreneurship, and we discuss policy options to tackle double disadvantage in deprived locales.
\end{abstract}

Keywords: Gender; Social exclusion; Spatial exclusion; Human capital; Entrepreneurship

\section{Introduction}

Research on disadvantage entrepreneurship has explored disadvantages on multiple fronts, including socio-demographics (Carter et al., 2015; Kushnirovich et al., 2017; Marlow and Swail, 2014), entrepreneurial capital (Dodd and Keles, 2014), and location (Naudé et al., 2008; Rouse and Jayawarna, 2006). For instance, we know that in many contexts, individuals belonging to certain social groups (e.g. females) are marked by the lack of (or diminished) access to entrepreneurial capital leading to limited entrepreneurial activity (Hughes et al., 2012; Marlow and Patton, 2005). However, we still have limited knowledge on how location disadvantages interact with existing disadvantages at socio-demographic (gender) and entrepreneurial capital (human capital) fronts in influencing entrepreneurial activity (Brush et al., 2017; Gill and Larson, 2014; Henry et al., 2016).

There exists a strong economic case for promoting women's entrepreneurship. For instance, one estimate is that if women started businesses at the same rate as men, then the United Kingdom (UK) would see 150,000 more businesses per annum creating 390,000 more 
jobs (UK Women's Enterprise Taskforce, 2012). We also know that harnessing entrepreneurship in disadvantaged areas could enhance economic development through job creation, increased productivity and social inclusion (Blackburn and Ram, 2006; Frankish et al., 2014; Welter et al., 2008). Given this economic relevance of both women's entrepreneurship and entrepreneurship in disadvantaged areas, it is important to have an integrated understanding of how spatially concentrated disadvantages (location) (Rae, 2012) interact with social disadvantages (gender) to influence business start-up activity, also known as nascent entrepreneurial activity. To this end, we address the following research question in this paper: what is the effect of spatially concentrated deprivation on gender differences in nascent entrepreneurial activity, accounting for gender differences in human capital in different locales?

We utilize the literature on human capital, intersectionality and mixed embeddedness to explore the research question. Human capital theory highlights the relevance of two types of human capital on entrepreneurial activity: general (education) and specific (entrepreneurial skills and experience) (Becker, 1976; Marvel et al., 2016). Intersectionality literature discusses privileges and disadvantages emanating from intersecting social positions of gender, race, and ethnicity (Gill and Larson, 2014; Martinez Dy et al., 2017; Wang and Warn, 2017). Gill and Larson (2014) extended the intersectionality argument to highlight the intersecting role of place-based effects. The mixed embeddedness approach allows us to explain entrepreneurship by situating entrepreneurial capabilities and opportunities within a socio-economic, spatial and regulatory context (Jones et al., 2014; Kloosterman, 2010; Ram et al., 2013). A critical element of intersectionality theory is that intersecting social positions have multiplicative rather than additive effects (Dubrow, 2008). We integrate these multiple theoretical strands to argue the presence of a 'double disadvantage' for women trying to start businesses in deprived locations, caused by the interaction of human capital disparities and locational disadvantages.

We use the empirical context of nascent entrepreneurial activity across different geographic locales in the United Kingdom to test our arguments. We combine the Global Entrepreneurship Monitor (GEM) database with Index of Multiple Deprivation (IMD) data for the period 2007-2012 to build the dataset. Our results offer support to our argument, highlighting the presence of a 'double-disadvantage' hampering female nascent entrepreneurial activity within deprived locales. 
We make multiple contributions through this study. Firstly, we contribute to the literature on disadvantage entrepreneurship (Blackburn and Ram, 2006; Carter et al., 2015; Kloosterman, 2010; Marlow and Swail, 2014; Ram et al., 2013) by highlighting the interaction of social and spatial exclusion on nascent entrepreneurial activity. Secondly, we add to the economic geography literature (Ghani et al., 2013; Langevang et al., 2015; Perucca et al., 2018; Rae, 2012) by exploring the effect of gender differences in human capital and deprivation on entrepreneurship across different locales. Finally, we extend the human capital literature (Estrin et al., 2016; Marvel et al., 2016) by studying the role of gender differences in human capital in different locales of the same country rather than at individual, firm or country-level.

\section{Theory and hypotheses development}

The term 'disadvantage entrepreneurship' has a range of meanings in the literature. Firstly, it could refer to entrepreneurs of a specific group like women (Marlow and Swail, 2014), immigrants (Kushnirovich et al., 2017), ex-prisoners (Cooney, 2012), old people (Curran and Blackburn, 2001), or disabled individuals (Dimic and Orlov, 2014) who experience social exclusion (Khan et al., 2015). Secondly, it can imply the geographical location of individuals and associated spatial inequalities (Naudé et al., 2008) arising from spatially concentrated deprivation (Rae, 2012; Rouse and Jayawarna, 2006). Finally, it might characterise individuals with disadvantages in terms of specific capabilities, skills, or perceptions (i.e. entrepreneurial capital) that enhance their vulnerability, such as discouraged borrowers (Dodd and Keles, 2014; Kon and Storey, 2003). In summary, the disadvantages for entrepreneurs can arise from their socio-economic characteristics, location, or capabilities (Carter et al., 2013).

Prior literature systematically classifies female entrepreneurs as disadvantaged compared to males, highlighting gender disparities in entrepreneurial intentions globally (Hughes et al., 2012; Marlow and Patton, 2005). There is evidence that women exhibit preferences towards flexible working hours and part-time involvement into self-employment, decreasing the scope of work experience and exposure to business opportunities, thus decreasing entrepreneurial start-up rates (Carter et al., 2015; Marlow et al., 2012). The disadvantaged position compared to men is also observed in relation to the accumulation of entrepreneurial resources (Jayawarna et al., 2015), education (Carter et al., 1997; Fischer et al., 1993), managerial skills (Zolin et al., 2013), social and professional networks (including socialisation experiences) (Jayawarna et al., 2015), and finance (Freel et al., 2012; Roper and 
Scott, 2009). Some studies suggest that women are risk-averse in relation to their business funding strategy (Coleman and Robb, 2012), however, this perspective was challenged with the argument that risk-avoidance among women is a consequence of shifting socio-economic norms, which are reflected in their entrepreneurial endeavours and actions (Marlow and Swail, 2014). In short, belonging to a particular social group, such as women in the UK, may be marked by the lack of (or diminished) access to human capital, resources and capabilities essential for launching a successful entrepreneurial activity.

Rates of entrepreneurial activity are negatively correlated with spatially concentrated deprivation (Devins, 2009; Frankish et al., 2014; Williams and Huggins, 2013; Williams et al., 2017; Williams and Williams, 2017). Also, female entrepreneurship rates are found to be correlated with human capital (Adom and Asare-Yeboa, 2016; Brush et al., 2017; Caliendo et al., 2014; Marvel et al., 2016). However, the mutual effects of these relationships have not been disentangled, despite Gunnerud's (1997, p.267) warning that "when studying entrepreneurs one should be aware of the fact that one studies gendered beings in gendered places". In other words, empirical studies have not yet confirmed whether a disadvantaged location further amplifies the disadvantage of a female entrepreneur in terms of involvement into entrepreneurial activity, as intersectionality theory might suggest. Therefore, our theoretical development will examine the impact of gender differences in human capital and spatially concentrated deprivation on the phase of entrepreneurial process where individuals are actively trying to start a business.

\section{Human capital and gender differences in entrepreneurial activity}

Human capital theory deals with individual decisions about career choices and investments into skills and knowledge (Becker, 1976). Becker (1994) differentiates two forms of human capital: general and specific human capital. In the context of entrepreneurship, the former refers to the educational qualifications, while the latter refers to having the knowledge, skills and experience to run a new business. Previous research related both forms of human capital with the career choice towards self-employment and entrepreneurship (Davidsson and Honig, 2003; Dimov, 2010; Kim et al., 2006; Passaro et al., 2018), its success (Unger et al., 2011), and exit decisions (Gimeno et al., 1997; Huggins et al., 2017).

A wide range of studies have positively linked entrepreneurial activity with different human capital dimensions (see Marvel et al. (2016) for a literature review). However, evidence 
on the effect of general human capital on entrepreneurial activity is mixed. On the one hand, for those with high general human capital, entrepreneurial activity might result in a greater probability of decreased income - or higher variability in possible income - in future compared to regular employment (Becker, 1962; Cassar, 2006). On the other hand, other evidence suggests that general human capital increases the likelihood that an individual will engage in entrepreneurial activity, as a result of knowledge, skills and confidence gained from education (Davidsson and Honig, 2003; Delmar and Davidsson, 2000; Piperopoulos and Dimov, 2015; Rotefoss and Kolvereid, 2005). The availability, and the consequent impact, of general human capital might vary across different opportunity creation contexts (Alvarez and Barney, 2014). Therefore, one could assume that the role of context is particularly important in such a relationship, revealing a gap in research on the impact of human capital on nascent entrepreneurial activity beyond the individual level (Marvel et al., 2016).

Research into specific human capital suggests more straightforward findings, where skills and knowledge associated with an entrepreneurial context make the individual better equipped to identify and exploit opportunities, and hence are considered to have a positive effect on nascent entrepreneurial activity (Clercq and Arenius, 2006; Sahasranamam \& Sud, 2016; Ucbasaran et al., 2008). Furthermore, specific human capital may also emanate from prior entrepreneurial experience or experience in a related industry to the new venture. It is argued that specific (entrepreneurial) human capital is of greater benefit to entrepreneurship (Unger et al., 2011) and is also more likely to be influenced by contextual factors when compared to general human capital (Estrin et al., 2016; Sahasranamam and Nandakumar, 2018). Taking a temporal view, scholars suggest that general human capital is more beneficial in the long-run, while specific human capital has greater benefits in the short term (Rauch and Rijsdijk, 2013).

In general, it is argued that female nascent entrepreneurs are disadvantaged compared to their male counterparts in terms of human capital for both household and societal reasons (Hindle et al., 2009; McGowan et al., 2015). These disparities mainly arise from the tendency for women to have work experience that is more limited in time and in scope, thus hindering the development of enterprising skills and social networks (Carter et al., 2003; Patterson and Mavin, 2009). Therefore, from a social exclusion perspective, women are viewed as a disadvantaged group, willing to engage in entrepreneurial activity, but with less access on 
average to resources and opportunities and less likely to possess the human capital necessary to convert one into the other (Abrams et al., 2008).

Summarising this discussion, differences in general human capital may affect both opportunity recognition and entrepreneurial self-efficacy, two critical preconditions for nascent entrepreneurial activity (Marvel et al., 2016). Gender differences in specific human capital cause relative disadvantage in entrepreneurship-specific skills like problem-solving, knowledge about markets and knowledge about customers (Shane, 2000). Controlling for other contextual factors, we would therefore expect to see a positive relationship between differences in general or specific human capital of men and women in a set of boundary spaces (such as geographical locales) and differences in nascent entrepreneurship rates of men and women in that set of boundary spaces. In other words, we hypothesize that there is a relationship between gender differences in general/specific human capital and gender differences in nascent entrepreneurial activity rates across locales:

H1: The greater the difference in the level of general human capital between women and men in a locale, the greater the difference in the level of nascent entrepreneurial activity between men and women.

H2: The greater the differences in the levels of specific human capital between women and men in a locale, the greater the difference in the level of nascent entrepreneurial activity between men and women.

\section{Spatially concentrated deprivation}

Spatially concentrated deprivation refers to lack of resources within a locale, which may be viewed in terms of income, material wealth, educational standards, nutritional levels, and infrastructure (Blackburn and Ram, 2006; Rae, 2012). A deprived locale is likely to be characterized by lack of market opportunities (Storey and Johnson, 1987), poor infrastructure and other support mechanisms (Slack, 2005; Taylor and Plummer, 2003; Welter et al., 2008) needed for entrepreneurship. Therefore, more deprived locales are likely to have lower levels of entrepreneurial activity than less deprived locales (Thompson et al., 2008; Williams and Williams, 2011). 
The level of deprivation in a locale imposes different roles on women in terms of social expectations regarding family and household (Allen and Truman, 2016). Moreover, higher levels of unemployment in deprived locales increase the likelihood that women will be more likely to be engaged in childcare and household duties and less likely to be engaged in any type of economic activity (Metcalf, 2013). Furthermore, women are more subject to socio-economic norms (Marlow and Swail, 2014) and thus tend to perceive the environment in a more negative light than men do (Langowitz and Minniti, 2007) and are more risk aware. This is likely to negatively impact the likelihood of nascent entrepreneurial activity among women in deprived areas, particularly in cultures where entrepreneurship is not viewed as a mainstream activity for women. In this regard, some researchers find that in deprived areas there exists a greater skew of resource acquisition and market advantages in favour of men (Bates, 2010; Jayawarna et al., 2011; Rouse and Jayawarna, 2011; Williams and Williams, 2011). Hence, women are likely to encounter greater difficulties in identifying and exploiting new business opportunities in deprived areas. Therefore, we hypothesize that:

H3: The higher the level of deprivation in a locale, the higher the level of gender differences in nascent entrepreneurial activity.

The concept of intersectionality suggests that the interaction between a range of discourses that socially construct disadvantage further magnifies disadvantage among individuals who identify across multiple socially disadvantaged groups, leading to exclusion (Crenshaw, 1997; Martinez Dy et al., 2014). It is argued that intersectionality of identities drives positionality, which refers to a dynamic position across social structures and agencies (Anthias, 2001), moderating the relationship between social disadvantage and resource allocation (e.g. human capital) (Martinez Dy et al., 2017). Entrepreneurial identity, a manifestation of occupational identity, is a mental process through which an individual constructs a reflective image of their own identity based on individual discourses, such as gender, social class, and ethnicity (Drakopoulou Dodd and Anderson, 2007), as well as environmental conditions, for example external influences, societal norms and expectations, and place (Gill and Larson, 2014). The evolution of such self-constructions will lead to the emergence of a dominant form of entrepreneurial identity in the society. As a result, a rigid perception in western cultures of the identity of an entrepreneur as a white, urban, male, young/middle-aged individual arises, imposing an additional psychological barrier for individuals not belonging to that identity to overcome (Ashcraft, 2007; Gill and Ganesh, 2007). 
The intersectionality perspective meshes well with the mixed embeddedness framework, where individuals are positioned geographically in a specific locale which provides them with a specific social and economic context that in turn presents specific opportunities and challenges for entrepreneurial activity (Dacin et al., 1999; Granovetter, 1985; Jack and Anderson, 2002; Ram et al., 2008). For example, local-level factors in combination with individual determinants and wider macroeconomic influences determine the availability of entrepreneurial capital (including human capital), which limits access to certain opportunities (Kloosterman, 2010).

Based on intersectionality theory and the mixed embeddedness framework, we can portray women in disadvantaged areas as encountering two discourses: location and gender, which influence their self-identity in relation to a male entrepreneur (Ashcraft, 2007; Drakopoulou Dodd and Anderson, 2007). Deprived locales are likely to have limited schooling facilities, reducing opportunities to build general human capital. Such areas are also known to have low entrepreneurship rates (Hughes et al., 2012), and relatively high unemployment (Bynner and Parsons, 2002), and this combination limits social exposure to entrepreneurship (Jayawarna et al., 2015). Therefore, individuals from these areas are likely to have lower levels of general and specific human capital (Lee and Cowling, 2013; Rouse and Jayawarna, 2006). On the gender front, entrepreneurial identity for males in disadvantaged locales will be determined by location alone, other things equal. However, women need to take cognizance of the dominant type of entrepreneurial identity in the society (illustrated earlier) and locational factors. Considering that the former effect is attributed to women but not men, and the latter effect to both genders, the position of women in terms of entrepreneurial activity is further aggravated in deprived locales compared to male counterparts. This is likely to hinder women in terms of their aspirations, abilities and access to resources needed to start a new venture. In summary, entrepreneurial identities, social hierarchies and locational disadvantages are likely to curtail both general and specific human capital acquisition and utilization by women towards entrepreneurship, leading to a double disadvantage. Therefore, we hypothesize that:

H4a: The relationship between gender differences in general human capital and gender differences in nascent entrepreneurial activity across different locales is negatively moderated by deprivation at the locale level. 
H4b: The relationship between gender differences in specific human capital and gender differences in nascent entrepreneurial activity across different locales is negatively moderated by deprivation at the locale level.

The final conceptual model is presented in Figure 1.

[Insert Figure 1 about here]

\section{Data and methods}

Sample

We combine the Global Entrepreneurship Monitor (GEM) data for United Kingdom with the Index of Multiple Deprivation (IMD) for the period 2007-2012 in this study. We use the GEM Adult Population Survey (APS) for data on individual characteristics and entrepreneurship rates within the adult population. Since 2001, GEM surveys are conducted annually in the UK and capture information on a wide range of entrepreneurship related factors through fixed line and mobile telephone interviews (Levie and Autio, 2008). GEM surveys are considered rich, reliable and valid (Reynolds et al., 2005), and have been extensively used in recent entrepreneurship research (Brush et al., 2017; Estrin et al., 2016).

Index of Multiple Deprivation (IMD) developed and collected by the Office of National Statistics (ONS) is used to capture deprivation across local areas in the UK. It reflects the socioeconomic environment of a locale and is available at the lower layer super output areas LSOAs (locales each containing around 1,500 people) across England, and similarly defined data zones in Wales, Scotland, and Northern Ireland, thus covering all four home nations in the UK. The indicators are calculated based on Census data and additional data from administrative sources. The rank-based index allows one to estimate the relative position of a locale in terms of deprivation, where a higher deprivation score implies a more deprived area (Noble et al., 2008).

The methodology of IMD calculation across the four home nations is different, making direct comparisons impossible within the UK. Income and employment deprivation domains are measured in the most consistent way, while other dimensions and their construction vary considerably (Department for Communities and Local Government; Northern Ireland Statistics 
and Research Agency; Stats Wales; The Scottish Government). For this study, the indices were adjusted to make them comparable both across years and home nations, as outlined below.

Following the methodology developed by Payne and Abel (2012), England indices are used as the baseline for the universal score, and a rank correlation coefficient (Kendall's tau) between adjusted and original IMD achieved 0.91 for Wales, 0.96 for Scotland, and 0.97 for Northern Ireland. To construct the adjusted scores, a linear regression model was computed for each home nation, with the overall IMD as the dependent variable, and income and employment domains as independent variables. The results of the modelling for each home nation are presented in Table 1. Next, residuals were obtained using those models, as an estimation of the unique contribution of other domains of deprivation (not income and employment) to the overall IMD. And, finally, the adjusted scores for each country were computed using the formula proposed by Payne and Abel (2012).

\section{[Insert Table 1 about here]}

Another amendment was made in relation to the time period for which the indicators are calculated. Within the observation period English IMD are available for 2007 and 2010, Welsh (WIMD) for 2008 and 2011, Scottish (SIMD) for 2006, 2009, and 2012, and Northern Irish (NIMDM) for 2010. As a result, two scores were computed: 1) for the pre-crisis period (IMD for 2007, WIMD for 2008, SIMD for 2006, and NIMDM for 2010); and 2) for the aftercrisis period (IMD for 2010, WIMD for 2011, SIMD for 2012, and NIMDM for 2010). The adjusted indices of multiple deprivation both for the pre-crisis and post-crisis periods were merged with the GEM data set according to the following procedure:

1) Postcodes associated with each individual in the GEM data set were matched with LSOAs (England and Wales), data zones (Scotland), and super output areas (Northern Ireland) through GeoConvert (UK Data Service Census Support);

2) Each LSOA, data zone, and super output area identified was matched with the adjusted IMD for the pre-crisis and post-crisis periods.

As a result, matched IMD were available for 78\% (the mean for the period 2007-2012) of the cases which ensured the representativeness of the sample. 
In order to address the research question at the locale level, we spatially clustered adjacent LSOAs in England, data zones in Scotland, and super output areas in Northern Ireland to create 197 locales across the four home nations based on the following criteria:

- Geographical adjacency of LSOAs, data zones, and super output areas;

- The grouping is confined by nations' geographical boundaries;

- The sample size is more than 600 observations in each locale;

- The final number of locales is large enough for an adequate statistical analysis.

Aggregating neighbouring LSOAs into larger locales allowed us to increase the sample size within each community, offering representativeness to estimate nascent entrepreneurship rates. Tables 2 and 3 present the summary characteristics after the aggregation.

[Insert Tables 2 and 3 about here]

Arguably, when combining LSOAs/data zones/super output areas into locales, contextual differences within these larger areas increase, giving rise to potential biases (e.g. Piantadosi et al., 1988). However, the aggregation of geographically adjacent small areas achieves homogeneity across IMD indicators within locales, so that IMD varies across them to capture the spatially concentrated deprivation phenomenon. Moreover, the analysis and implication are derived at the locale level, avoiding making inferences about individuals. To tackle spatial mobility issues associated with deprivation and generally acknowledged in the literature (Frankish et al., 2014; Sutter et al., 2019), additional checks were carried out, and these showed minor effects on results at the locale level of analysis. Comparing home and business locations of individual nascent entrepreneurs in the sample, between eight and nine out of ten home and business postcodes match. As a result, spatial homogeneity is preserved within each locale, which makes it possible to examine spatially concentrated deprivation varying across those areas in line with the argument of Rae (2012) about its significance.

\section{Dependent variable}

Our dependent variable is the gender ratio (female to male) in nascent entrepreneurial activity at the locale (spatially clustered LSOAs) level. GEM captures individual level nascent entrepreneurial activity based on whether individuals are actively involved in start-up effort 
for a business they will own and manage in whole or in part (Hechavarría and Ingram, 2018). We aggregate this to the locale level; the mean value is specified in Table 4.

\section{Independent variables}

General human capital gender ratios and specific human capital gender ratios at the locale level are measured as mean aggregate ratios computed from the individual level data (see descriptive statistics in Table 4). At the individual level, general human capital is operationalized based on whether respondents have post-secondary level educational qualifications (Estrin et al., 2016; Sahasranamam and Raman, 2018). Individual specific human capital is a perception-based measure of whether individuals believe that they have the skills, knowledge and experience to start a new business (Sahasranamam and Nandakumar, 2018). As highlighted earlier, spatially concentrated deprivation was measured using the mean IMD value aggregated at the locale level.

\section{Control variables}

Following prior research (Hechavarría and Ingram, 2018; Huggins et al., 2017), we use multiple control variables at the locale level. We control for socio-demographic factors like average age and household income. We also control for multiple entrepreneurial culture related factors at the locale level including knowing an entrepreneur who has recently started a business, media perception of entrepreneurs and status associated with entrepreneurs (see Table 4 for details). In addition, we control for the stage of the economy (2007: pre-recession stage; 2008-2009: recession stage; 2010-2012: post-recession stage) using dummy variables.

\section{Estimation}

Table 4 summarizes our variables, their operationalization and summary statistics. In Table 5, we present the correlation matrix. From this, we observe that there are no very high correlations between the variables. In our regression models, we further tested for multicollinearity and observed that VIF statistics were within the range of 4 (Cohen et al., 2003; Neter et al., 1996). In addition, we also noted that the overall condition number was less than 15. These suggest that (Belsley et al., 2005) multi-collinearity is not a serious concern in our study. We performed OLS regression to test our hypotheses. In order to overcome heteroscedasticity concerns in aggregated data, we used robust standard errors in the analysis. 


\section{Results}

In Table 6, we present the results from OLS regression. Model 1 presents the results for the control variables. In Models 2, 3 and 4, we include the independent variables general human capital gender ratio, specific human capital gender ratio and spatially concentrated deprivation, respectively. From Model 2, we find support for Hypothesis 1, as we observe a positive and significant relationship between general human capital gender ratio and nascent entrepreneurial activity gender ratio $(\beta=0.44, \mathrm{p}<0.001)$. Similarly, we notice a positive and significant relationship between specific human capital gender ratio and nascent entrepreneurial activity gender ratio $(\beta=1.52, \mathrm{p}<0.001)$ in Model 3. This illustrates support for Hypothesis 2 . However, in Model 4, we observe a negative and significant effect of spatially concentrated deprivation on nascent entrepreneurial activity gender ratio $(\beta=-0.07, p<0.001)$, suggesting that in more deprived locales men are more likely to exhibit higher nascent entrepreneurial activity, lending support to Hypothesis 3. Models 5 and 6 present the results for interaction between human capital gender ratio variables and spatially concentrated deprivation. We mean centred the interaction terms before entering them into the regression model. We find that spatially concentrated deprivation has a negative and significant moderating effect on the relationship between the general human capital gender ratio and the nascent entrepreneurial activity gender ratio $(\beta=-0.04, \mathrm{p}<0.001)$ and the relationship between the specific human capital gender ratio and the nascent entrepreneurial activity gender ratio $(\beta=-0.02, p<0.001)$. This offers support for Hypotheses $4 \mathrm{a}$ and $4 \mathrm{~b}$.

[Insert Tables 4, 5 and 6 about here]

While testing interaction effects, the direction and statistical significance of the interaction terms are likely to vary for different values of independent variables (Hoetker, 2007; Zelner, 2009). Therefore, it is important to not interpret the interaction term by examining the 
direction, magnitude and statistical significance of the resulting coefficients alone (Maekelburger et al., 2012). Hence, we plot the interaction effects in Figures 2a and 2b.

\section{[Insert Figures $2 \mathrm{a}$ and $2 \mathrm{~b}$ about here]}

Figures $2 \mathrm{a}$ and $3 \mathrm{~b}$ suggest that in locales with low deprivation, women appear to significantly narrow the nascent entrepreneurial activity gap with men, where they have high general or specific human capital relative to men, but in locales with high deprivation, there is no human capital boost. Deprivation appears to prevent women from benefiting from any human capital advantages they might have. This empirical result is subtly different to that proposed by intersectionality theory and embeddedness theory.

Amongst the control variables, we find that age, household income, and media perception of entrepreneurs have a positive and significant effect, while social capital with another recently started entrepreneur and status associated with entrepreneurs has a negative and significant impact at the locale level. From a social demographics point of view, these results suggest that in areas where average age and household income are higher, women are likely to exhibit greater entrepreneurial activity compared to men. Access to finance creates more favourable conditions for entrepreneurial action (Alvarez et al., 2011; Urbano and Alvarez, 2014; Vuong et al., 2016), and since financial barriers are especially acute for women (Brush et al., 2018), this result makes sense. At the level of entrepreneurial culture within locales, the results suggest that positive media perception of entrepreneurship may encourage entrepreneurial activity among women compared to men. However, knowing another recently started entrepreneur and status associated with entrepreneurship may be less important drivers of nascent entrepreneurial activity among women than men. This is also consistent with prior literature, which suggests that women gain less from entrepreneurial networks from men (FarrWharton and Brunetto, 2007; Runyan et al., 2006; Santos et al., 2016) and also value status less than safety, family, and work-life balance relative to men, in entrepreneurial and other contexts (Cliff, 1998; Poggesi et al., 2016).

\section{Robustness tests}


We conducted multiple robustness checks, which support our findings. Firstly, we conducted the entire analysis replacing nascent entrepreneurship gender ratio with early stage entrepreneurial activity (TEA) ${ }^{1}$ gender ratio and found similar results. We also utilized an alternative measure for specific human capital composed of individuals' perception of risk, capabilities and social networks (Arenius and Minniti, 2005) and obtained consistent results. Finally, considering that the data on deprivation for Northern Ireland was available only for 2010, we replicated the analysis without including Northern Irish data to find similar results.

\section{Discussion}

Our results reinforce previous findings which identify female entrepreneurs as disadvantaged in terms of their access to human capital (Hindle et al., 2009; Marvel et al., 2016; McGowan et al., 2015) and location (Jayawarna et al., 2011; Rouse and Jayawarna, 2011; Williams and Williams, 2011), but build on these to demonstrate a multiplicative effect of human capital and deprivation on nascent entrepreneurship rates at the locale level for women relative to men. In line with intersectionality theory (Martinez Dy et al., 2017), but subtly different to the literature, we find that deprivation prevents women from taking advantage of any human capital assets they might have that are relevant to engagement in nascent entrepreneurial activity. One interpretation might be that while women are exposed to the same obstacles as men in deprived locales in terms of socio-demographic factors (Lee and Cowling, 2013), social capital (Lee et al., 2018), and perceptions (Williams and Williams, 2011), women may find it more challenging to overcome those potential barriers due to family burdens (Patrick et al., 2016), motivations (McGowan et al., 2012), differences in risk aversion (Fossen, 2012), trusting behaviours (Farr-Wharton and Brunetto, 2007) and socio-economic norms (Marlow and Swail, 2014) that their counterparts in less deprived areas do not face. Our empirical confirmation of a "double disadvantage" suggests it is much more difficult for women to break through the vicious circle of deprivation, even if they have the human capital necessary for entrepreneurship, despite the evidence suggesting that entrepreneurship offers a route for people out of deprived areas (Frankish et al., 2014; Sutter et al., 2019). This is the first contribution of our paper to the literature on disadvantaged entrepreneurship.

\footnotetext{
${ }^{1}$ Individual who are either nascent entrepreneur (actively involved in start-up effort) or new entrepreneurs (owner managers of a business that is less than 42 months old).
} 
Entrepreneurship is linked to innovation and economic growth at both national and regional levels (Stephens et al., 2013; Vuong et al., 2013). If this logic can be transferred to the less than regional level of locales, then our findings suggest that the doubly disadvantaged position of women deters deprived locales from potential prosperity through new business activity (Doms et al., 2010; Spigel, 2017). This is the main implication of our first contribution.

Secondly, we add to the literature on economy geography by exploring locale level effects on entrepreneurship (Ghani et al., 2013; Langevang et al., 2015). Our findings suggest that spatially concentrated deprivation magnifies disadvantages faced by the socially excluded, and specifically in our study, women, in line with other studies of deprivation (Perucca et al., 2018). We know that deprivation within the UK is highly spatially concentrated and persists over time (Rae, 2012). Therefore, the social and spatial disadvantages associated with entrepreneurial activity are also likely to persist over time without external intervention, highlighting the need for focused policy attention. Entrepreneurship is viewed as an empowering and emancipatory device for women in contexts of deprivation, conflict and displacement like Northern Africa and Middle East (Al-Dajani et al., 2015). Given this, and the findings of Frankish et al. (2014) that entrepreneurship can be a route out of deprivation in the UK, our results suggest that more focused effort on assisting nascent entrepreneurship among women than men in deprived locales is justified (Bullough et al., 2015).

Recent research on regional entrepreneurship (Audretsch et al., 2017; Stuetzer et al., 2018 ) is gravitating towards the notion of entrepreneurial ecosystems (Spigel, 2017), where local government initiatives only partly address gaps and stimulate the equality of opportunities (Huggins and Thompson, 2015; Stam, 2015), and a rich network of active stakeholders is needed if the ecosystem is to thrive. Deprived locales are least likely to have such stakeholders. Viewing entrepreneurship as emancipation, allowing individuals to breakthrough constraints, and liberate themselves to pursue their aspirations (Rindova et al., 2009), echoes the previous argument about entrepreneurship as a route out deprivation, but is particularly difficult for women, acting within the boundaries of their households, social expectations, values, and norms (Jennings et al., 2016), even if they have the human capital necessary for entrepreneurship. In this vein, 'unisex' local policies alone will not address spatial disadvantage for women, which is more deeply rooted. Moreover, additional training and financial support won't help overcome the barriers associated with childcare, marital life, and 
other contingencies (Patrick et al., 2016), meaning that spatial deprivation requires a closer look at local community structures to understand its effects on women.

Our findings fit with other evidence that women are more likely to be pulled into entrepreneurial activity in more munificent areas (Glaeser et al., 2010). Specifically, our results suggest that this is because women in munificent areas benefit from their human capital endowments, whereas women in deprived areas do not. However, it is generally observed that most women are pushed into entrepreneurship (Patrick et al., 2016). In intersectionality theory, motivation shapes entrepreneurial identity, where high levels of self-efficacy, confidence, and opportunistic outlook 'pull' entrepreneurship among men (DeTienne and Chandler, 2007; Hart et al., 2017). This creates additional barriers for women to overcome psychologically. Moreover, low human capital endowment has been shown to correlate with necessity (or 'push') entrepreneurship (Block et al., 2015; van der Zwan et al., 2016), indicating that motivation can be viewed as a root of gender-related disadvantage. Our findings suggest a link between human capital, deprivation and motivation which is worth exploring in further work at the individual level.

Finally, we also make additional contributions to the literature on human capital and entrepreneurship. We already know about the role of human capital on entrepreneurship at the individual (Davidsson and Honig, 2003), firm (Marvel et al., 2016), and country levels (Brush et al., 2017). We extend this by studying gender ratio at the less than regional level (which we call the locale) and identify that locales with differences in human capital levels across genders are likely to lead to inequality in entrepreneurial rates across genders. We also contextualize this effect by highlighting the contingent role of spatially concentrated deprivation, supporting the mixed embeddedness perspective (Reuschke et al., 2015).

\section{Conclusions}

Our study contextualizes the relationship between gender ratio in human capital and gender ratio in entrepreneurial activity at the less-than-regional level within the UK. Combining the perspectives of human capital, intersectionality and positionality in the mixed embeddedness framework, we theorize a double-disadvantage effect faced by female entrepreneurs in deprived areas. Prior research applying the concept of intersectionality at the individual level has informed us of the constructed identity of female entrepreneurs (Martinez Dy et al., 2017; Wang and Warn, 2017). We embed this within locales to explain associations 
between relative human capital of women and men at the level of the locale and associated gender disparities in entrepreneurial activity, and further link this to the moderating effect of spatially concentrated deprivation.

Our results suggest that women in a locale are not only disadvantaged in terms of human capital when starting a new business compared to men, but also any human capital advantage they might possess is neutralised by local deprivation, imposing a double disadvantage effect. The disadvantaged position of women in terms of human capital is already well researched in the literature on social exclusion at the individual level (Bernat et al., 2017; Fairlie and Robb, 2007; Thiess et al., 2015). However, our findings embed the relationship between the gender ratio in human capital and the gender ratio in entrepreneurial activity in a geographical context.

\section{Policy implications}

There is much contemporary interest around issues of gender pay differences, both in full or part-time employment (Olsen et al., 2018), and self-employment (Department for Business Innovation and Skills, 2016). This indicates that social exclusion of women is still persistent despite governmental efforts to address inequality by offering support to female entrepreneurs to fill gaps in their human capital acquisition. Some local enterprise growth initiatives attempt to tackle deprivation through encouraging entrepreneurial activity in deprived areas by introducing various forms of support, including investments into human capital (Local Government Improvement and Development, 2010; The Baroness Mone OBE, 2016). Considering the importance of gender disparity and deprivation in the political agenda, our results throw light on the compounding effect of social and spatial exclusion on women. Our findings suggest that the gender ratio in entrepreneurial activity is affected by the deprivation level of a local area, which further constrains the availability and utilization of both general and specific human capital by women towards entrepreneurship. Therefore, it is not merely the availability of local support schemes that matters in addressing this issue, but the consideration of a broader social context (Jayawarna et al., 2015; Marlow and Swail, 2014), where the social role of women, societal expectations, and other pressures of deprived areas hinder the prospects of gender equality in entrepreneurial activity.

\section{Limitations and Future Research}


There are two main limitations associated with the study. The first one relates to the operationalization issues arising from the nature of the dataset. The categorization of general and specific human capital is limited to the variables available in the GEM dataset across geographical space. Human capital measures could encompass a broader range of parameters, reflecting a richer definition adopted in selected studies (Martin et al., 2013; Marvel et al., 2016). For instance, certain dimensions of task-specific and general human capital, such as the type of formal education, entrepreneurial training, participation in local mentoring skills (Marvel et al., 2016) may be used in future research for developing a more fine-grained understanding. Other approaches, such as the measurement of entrepreneurial mindset (Ahmetoglu and Chamorro-Premuzic, 2017) could be attempted.

The second limitation refers to the contextualization aspect. Although satisfying the pursued research objective by relying on a multidimensional construct of multiple deprivation, future studies could consider each deprivation domain (income, employment, education, health, living environment, housing, and crime) separately. Future research may also include other measures to characterize the availability of social capital (Kang and Snell, 2009) and local support infrastructure (McKeever et al., 2015; Santos et al., 2016). For instance, scholars have noted that social capital can aid entrepreneurs in their resource acquisition efforts within deprived areas (Lee et al., 2018; Sahasranamam and Ball, 2018). This research could be extended to understand how such social capital aided resource acquisition efforts vary with respect to gender. In addition, individual and community level discourses could be analysed within the mixed embeddedness perspective by disentangling complexities in the interaction of different-level factors (Romero and Valdez, 2016; Wang and Warn, 2017). This would offer scope for multilevel analysis to explain different inclination towards entrepreneurial activity between men and women. The focus of this study was on gender and deprivation; further studies could add other social discourses that have been shown to generate disadvantage such as ethnic identity or immigrant status.

It would also be interesting to replicate this study in emerging market contexts such as India or China where the role of gender and institutional characteristics on entrepreneurship are observed to be different from developed markets (Chatterjee and Sahasranamam, 2018; Sahasranamam and Ball, 2016). Moreover, future research could adopt a qualitative understanding of human capital (Dimov, 2017), wherein a typology of female entrepreneurs 
could be derived based on their human capital and contextual parameters by means of fuzzyset methodology. 


\section{References}

Abrams, D., Christian, J., and Gordon, D. 2008. Multidisciplinary handbook of social exclusion research: John Wiley \& Sons.

Adom, K., and Asare-Yeboa, I. T. 2016. "An evaluation of human capital theory and female entrepreneurship in sub-Sahara Africa: Some evidence from Ghana". International Journal of Gender and Entrepreneurship, 8(4): 402-423.

Ahmetoglu, G., and Chamorro-Premuzic, T. 2017. "An Individual Differences Approach to Studying Entrepreneurial Tendencies". The Wiley Handbook of Entrepreneurship: 231-255.

Al-Dajani, H., Carter, S., Shaw, E., and Marlow, S. 2015. "Entrepreneurship among the displaced and dispossessed: Exploring the limits of emancipatory entrepreneuring". British Journal of Management, 26(4): 713-730.

Allen, S., and Truman, C. 2016. Women in business: Perspectives on women entrepreneurs. London: Routledge.

Alvarez, C., Urbano, D., Coduras, A., and Ruiz-Navarro, J. 2011. "Environmental conditions and entrepreneurial activity: a regional comparison in Spain". Journal of Small Business and Enterprise Development, 18(1): 120-140.

Alvarez, S. A., and Barney, J. B. 2014. "Entrepreneurial opportunities and poverty alleviation". Entrepreneurship Theory and Practice, 38(1): 159-184.

Anthias, F. 2001. "The material and the symbolic in theorizing social stratification: issues of gender, ethnicity and class". The British Journal of Sociology, 52(3): 367-390.

Arenius, P., and Minniti, M. 2005. "Perceptual variables and nascent entrepreneurship". Small Business Economics, 24(3): 233-247.

Ashcraft, K. L. 2007. "Appreciating the 'work' of discourse: Occupational identity and difference as organizing mechanisms in the case of commercial airline pilots". Discourse \& Communication, 1(1): 9-36.

Audretsch, D. B., Obschonka, M., Gosling, S. D., and Potter, J. 2017. "A new perspective on entrepreneurial regions: linking cultural identity with latent and manifest entrepreneurship". Small Business Economics, 48(3): 681-697.

Bates, T. 2010. "Alleviating the financial capital barriers impeding business development in inner cities". Journal of the American Planning Association, 76(3): 349-362.

Becker, G. S. 1962. "Investment in human capital: A theoretical analysis". The Journal of Political Economy, 70(5): 9-49. 
Becker, G. S. 1994. "Human capital revisited", Human Capital: $\boldsymbol{A}$ Theoretical and Empirical Analysis with Special Reference to Education (3rd Edition): 15-28: The University of Chicago Press.

Becker, S. G. 1976. The Economic Approach to Human Behaviour. Chicago and London: The University of Chicago Press.

Belsley, D. A., Kuh, E., and Welsch, R. E. 2005. Regression diagnostics: Identifying influential data and sources of collinearity. New York: John Wiley \& Sons.

Bernat, L. F., Lambardi, G., and Palacios, P. 2017. "Determinants of the entrepreneurial gender gap in Latin America". Small Business Economics, 48(3): 727-752.

Blackburn, R., and Ram, M. 2006. "Fix or fixation? The contributions and limitations of entrepreneurship and small firms to combating social exclusion". Entrepreneurship and Regional Development, 18(1): 73-89.

Block, J. H., Kohn, K., Miller, D., and Ullrich, K. 2015. "Necessity entrepreneurship and competitive strategy". Small Business Economics, 44(1): 37-54.

Brush, C., Ali, A., Kelley, D., and Greene, P. 2017. "The influence of human capital factors and context on women's entrepreneurship: Which matters more?". Journal of Business Venturing Insights, 8: 105-113.

Brush, C., Greene, P., Balachandra, L., and Davis, A. 2018. "The gender gap in venture capital-progress, problems, and perspectives". Venture Capital, 20(2): 115-136.

Bullough, A., De Luque, M. S., Abdelzaher, D., and Heim, W. 2015. "Developing women leaders through entrepreneurship education and training". Academy of Management Perspectives, 29(2): 250-270.

Bynner, J., and Parsons, S. 2002. "Social exclusion and the transition from school to work: The case of young people not in education, employment, or training (NEET)". Journal of Vocational Behavior, 60(2): 289-309.

Caliendo, M., Fossen, F. M., Kritikos, A., and Wetter, M. 2014. "The gender gap in entrepreneurship: Not just a matter of personality". CESifo Economic Studies, 61(1): 202-238.

Carter, N., Brush, C., Greene, P., Gatewood, E., and Hart, M. 2003. "Women entrepreneurs who break through to equity financing: the influence of human, social and financial capital". Venture Capital: An International Journal of Entrepreneurial Finance, 5(1): 1369-1066.

Carter, N. M., Williams, M., and Reynolds, P. D. 1997. "Discontinuance among new firms in retail: The influence of initial resources, strategy, and gender". Journal of Business Venturing, 12(2): 125-145. 
Carter, S., Mwaura, S., Ram, M., Trehan, K., and Jones, T. 2015. "Barriers to ethnic minority and women's enterprise: Existing evidence, policy tensions and unsettled questions". International Small Business Journal, 33(1): 49-69.

Carter, S., Ram, M., Trehan, K., and Jones, T. 2013. Diversity and SMEs: Existing Evidence and Policy Tensions, Enterprise Research Centre White Paper, Vol. 3: Warwick Business School.

Cassar, G. 2006. "Entrepreneur opportunity costs and intended venture growth". Journal of Business Venturing, 21(5): 610-632.

Chatterjee, D., and Sahasranamam, S. 2018. "Technological innovation research in China and India: A bibliometric analysis for the period 1991-2015". Management and Organization Review, 14(1): 179-221.

Clercq, D. D., and Arenius, P. 2006. "The role of knowledge in business start-up activity". International Small Business Journal, 24(4): 339-358.

Cliff, J. E. 1998. "Does one size fit all? Exploring the relationship between attitudes towards growth, gender, and business size". Journal of Business Venturing, 13(6): 523-542.

Cohen, J., Cohen, P., West, S. G., and Aiken, L. S. 2003. Applied multiple regression/correlation analysis for the behavioral sciences (3rd ed.). New Jersey: Routledge.

Coleman, J. S., and Robb, A. 2012. A Rising Tide: Financing Strategies for Women Owned Firms. Stanford, CA: Stanford University Press.

Cooney, T. M. 2012. "Reducing recidivism through entrepreneurship programmes in prisons". The International Journal of Entrepreneurship and Innovation, 13(2): 125133.

Corbett, A. C. 2007. "Learning asymmetries and the discovery of entrepreneurial opportunities". Journal of Business Venturing, 22(1): 97-118.

Crenshaw, K. 1997. "Intersectionality and identity politics: Learning from violence against women of colour". In M. L. Shanley, \& N. U. (Eds.), Reconstructing Political Theory: 178-193. Oxford: Polity Press.

Curran, J., and Blackburn, R. A. 2001. "Older people and the enterprise society: Age and self-employment propensities". Work, Employment and Society, 15(4): 889-902.

Dacin, M. T., Ventresca, M. J., and Beal, B. D. 1999. "The embeddedness of organizations: Dialogue \& directions". Journal of Management, 25(3): 317-356.

Davidsson, P., and Honig, B. 2003. "The role of social and human capital among nascent entrepreneurs". Journal of Business Venturing, 18(3): 301-331. 
Delmar, F., and Davidsson, P. 2000. "Where do they come from? Prevalence and characteristics of nascent entrepreneurs". Entrepreneurship \& Regional Development, 12(1): $1-23$.

Department for Business Innovation and Skills. 2016. The income of the self-employed.

Department for Communities and Local Government. English Indices of Deprivation.

DeTienne, D. R., and Chandler, G. N. 2007. "The role of gender in opportunity identification". Entrepreneurship Theory and Practice, 31(3): 365-386.

Devins, D. 2009. "Enterprise in deprived areas: what role for start-ups?". International Journal of Entrepreneurship and Small Business, 8(4): 486-498.

Dimic, N., and Orlov, V. 2014. "Entrepreneurial tendencies among people with ADHD". International Review of Entrepreneurship, 13(3): 187-204.

Dimov, D. 2010. "Nascent entrepreneurs and venture emergence: Opportunity confidence, human capital, and early planning". Journal of Management Studies, 47(6): 11231153.

Dimov, D. 2017. "Towards a qualitative understanding of human capital in entrepreneurship research". International Journal of Entrepreneurial Behavior \& Research, 23(2): 210227.

Dodd, S. D., and Keles, J. 2014. Expanding the networks of disadvantaged entrepreneurs: OECD Technical Report. OECD Local Economic and Employment Development Programme.

Doms, M., Lewis, E., and Robb, A. 2010. "Local labor force education, new business characteristics, and firm performance". Journal of Urban Economics, 67(1): 61-77.

Drakopoulou Dodd, S., and Anderson, A. R. 2007. "Mumpsimus and the mything of the individualistic entrepreneur". International Small Business Journal, 25(4): 341-360.

Dubrow, J. K. 2008. "How can we account for intersectionality in quantitative analysis of survey data? Empirical illustration for Central and Eastern Europe". ASK: Society, Research, Methods, 17: 85-102.

Estrin, S., Mickiewicz, T., and Stephan, U. 2016. "Human capital in social and commercial entrepreneurship". Journal of Business Venturing, 31(4): 449-467.

Fairlie, R. W., and Robb, A. 2007. "Families, human capital, and small business: Evidence from the characteristics of business owners survey". ILR Review, 60(2): 225-245.

Farr-Wharton, R., and Brunetto, Y. 2007. "Women entrepreneurs, opportunity recognition and government-sponsored business networks: A social capital perspective". Women in Management Review, 22(3): 187-207. 
Fischer, E. M., Reuber, A. R., and Dyke, L. S. 1993. "A theoretical overview and extension of research on sex, gender, and entrepreneurship". Journal of Business Venturing, 8(2): 151-168.

Fossen, F. M. 2012. "Gender differences in entrepreneurial choice and risk aversion-a decomposition based on a microeconometric model". Applied Economics, 44(14): 1795-1812.

Frankish, J. S., Roberts, R. G., Coad, A., and Storey, D. J. 2014. "Is entrepreneurship a route out of deprivation?". Regional Studies, 48(6): 1090-1107.

Freel, M., Carter, S., Tagg, S., and Mason, C. 2012. "The latent demand for bank debt: characterizing "discouraged borrowers"". Small Business Economics, 38(4): 399-418.

Ghani, E., Kerr, W. R., and O'connell, S. D. 2013. "Local industrial structures and female entrepreneurship in India". Journal of Economic Geography, 13(6): 929-964.

Gill, R., and Ganesh, S. 2007. "Empowerment, constraint, and the entrepreneurial self: A study of white women entrepreneurs". Journal of Applied Communication Research, 35(3): 268-293.

Gill, R., and Larson, G. S. 2014. "Making the ideal (local) entrepreneur: Place and the regional development of high-tech entrepreneurial identity". Human Relations, 67(5): 519-542.

Gimeno, J., Folta, T. B., Cooper, A. C., and Woo, C. Y. 1997. "Survival of the fittest? Entrepreneurial human capital and the persistence of underperforming firms". Administrative Science Quarterly: 750-783.

Glaeser, E. L., Rosenthal, S. S., and Strange, W. C. 2010. "Urban economics and entrepreneurship". Journal of Urban Economics, 67(1): 1-14.

Granovetter, M. 1985. "Economic action and social structure: the problem of embeddedness". American Journal of Sociology, 91(3): 481-510.

Gunnerud, B.N. 1997. "Gender, place and entrepreneurship". Entrepreneurship \& Regional Development,9(3): 259-268.

Hart, M., Levie, J., Bonner, K., and Heere, L. 2017. "Global Entrepreneurship Monitor 2017 United Kingdom Monitoring Report".

Hechavarría, D. M., and Ingram, A. E. 2018. "Entrepreneurial ecosystem conditions and gendered national-level entrepreneurial activity: a 14-year panel study of GEM". Small Business Economics: 1-28.

Henry, C., Foss, L., and Ahl, H. 2016. "Gender and entrepreneurship research: A review of methodological approaches". International Small Business Journal, 34(3): 217-241.

Hindle, K., Klyver, K., and Jennings, D. F. 2009. "An "informed" intent model: Incorporating human capital, social capital, and gender variables into the theoretical 
model of entrepreneurial intentions", Understanding the Entrepreneurial Mind: 3550: Springer.

Hoetker, G. 2007. "The use of logit and probit models in strategic management research: Critical issues". Strategic Management Journal, 28(4): 331-343.

Huggins, R., Prokop, D., and Thompson, P. 2017. "Entrepreneurship and the determinants of firm survival within regions: human capital, growth motivation and locational conditions". Entrepreneurship \& Regional Development, 29(3-4): 357-389.

Huggins, R., and Thompson, P. 2015. "Entrepreneurship, innovation and regional growth: a network theory". Small Business Economics, 45(1): 103-128.

Hughes, K. D., Jennings, J. E., Brush, C., Carter, S., and Welter, F. 2012. "Extending women's entrepreneurship research in new directions". Entrepreneurship Theory and Practice, 36(3): 429-442.

Jack, S. L., and Anderson, A. R. 2002. "The effects of embeddedness on the entrepreneurial process". Journal of Business Venturing, 17(5): 467-487.

Jayawarna, D., Jones, O., and Macpherson, A. 2011. "New business creation and regional development: Enhancing resource acquisition in areas of social deprivation". Entrepreneurship \& Regional Development, 23(9-10): 735-761.

Jayawarna, D., Jones, O., and Marlow, S. 2015. "The influence of gender upon social networks and bootstrapping behaviours". Scandinavian Journal of Management, 31(3): 316-329.

Jennings, J. E., Jennings, P. D., and Sharifian, M. 2016. "Living the dream? Assessing the "entrepreneurship as emancipation" perspective in a developed region". Entrepreneurship Theory and Practice, 40(1): 81-110.

Jones, T., Ram, M., Edwards, P., Kiselinchev, A., and Muchenje, L. 2014. "Mixed embeddedness and new migrant enterprise in the UK". Entrepreneurship \& Regional Development, 26(5-6): 500-520.

Kang, S. C., and Snell, S. A. 2009. "Intellectual capital architectures and ambidextrous learning: a framework for human resource management". Journal of Management Studies, 46(1): 65-92.

Khan, S., Combaz, E., and McAslan Fraser, E. 2015. Social exclusion: topic guide, Revised Edition ed. Birmingham, UK: GSDRC, University of Birmingham.

Kim, P. H., Aldrich, H. E., and Keister, L. A. 2006. "Access (not) denied: The impact of financial, human, and cultural capital on entrepreneurial entryin the United States". Small Business Economics, 27(1): 5-22.

Kloosterman, R. C. 2010. "Matching opportunities with resources: A framework for analysing (migrant) entrepreneurship from a mixed embeddedness perspective". Entrepreneurship and Regional Development, 22(1): 25-45. 
Kon, Y., and Storey, D. J. 2003. "A theory of discouraged borrowers". Small Business Economics, 21(1): 37-49.

Kushnirovich, N., Heilbrunn, S., and Davidovich, L. 2018. "Diversity of entrepreneurial perceptions: immigrants vs. native population". European Management Review, 15(3): 341-355.

Langevang, T., Gough, K. V., Yankson, P. W., Owusu, G., and Osei, R. 2015. "Bounded entrepreneurial vitality: The mixed embeddedness of female entrepreneurship". Economic Geography, 91(4): 449-473.

Langowitz, N., and Minniti, M. 2007. "The entrepreneurial propensity of women". Entrepreneurship Theory and Practice, 31(3): 341-364.

Lee, N., and Cowling, M. 2013. "Place, sorting effects and barriers to enterprise in deprived areas: Different problems or different firms?". International Small Business Journal, 31(8): 914-937.

Lee, R., Tuselmann, H., Jayawarna, D., and Rouse, J. 2018. "Effects of structural, relational and cognitive social capital on resource acquisition: a study of entrepreneurs residing in multiply deprived areas". Entrepreneurship \& Regional Development: 1-21.

Levie, J., and Autio, E. 2008. "A theoretical grounding and test of the GEM model". Small Business Economics, 31(3): 235-263.

Local Government Improvement and Development. 2010. Supporting enterprise growth in deprived areas: A good practice guide for councils and local enterprise partnerships.

Maekelburger, B., Schwens, C., and Kabst, R. 2012. "Asset specificity and foreign market entry mode choice of small and medium-sized enterprises: The moderating influence of knowledge safeguards and institutional safeguards". Journal of International Business Studies, 43(5): 458-476.

Marlow, S., Hart, M., Levie, J., and Shamsul, M. K. 2012. Women in enterprise: a different perspective: RBS Group.

Marlow, S., and Patton, D. 2005. "All credit to men? Entrepreneurship, finance, and gender". Entrepreneurship Theory and Practice, 29(6): 717-735.

Marlow, S., and Swail, J. 2014. "Gender, risk and finance: why can't a woman be more like a man?". Entrepreneurship \& Regional Development, 26(1-2): 80-96.

Martin, B. C., McNally, J. J., and Kay, M. J. 2013. "Examining the formation of human capital in entrepreneurship: A meta-analysis of entrepreneurship education outcomes". Journal of Business Venturing, 28(2): 211-224.

Martinez Dy, A., Marlow, S., and Martin, L. 2017. "A Web of opportunity or the same old story? Women digital entrepreneurs and intersectionality theory". Human Relations, 70(3): 286-311. 
Martinez Dy, A., Martin, L., and Marlow, S. 2014. "Developing a critical realist positional approach to intersectionality". Journal of Critical Realism, 13(5): 447-466.

Marvel, M. R., Davis, J. L., and Sproul, C. R. 2016. "Human capital and entrepreneurship research: A critical review and future directions". Entrepreneurship Theory and Practice, 40(3): 599-626.

McGowan, P., Cooper, S., Durkin, M., and O'Kane, C. 2015. "The influence of social and human capital in developing young women as entrepreneurial business leaders". Journal of Small Business Management, 53(3): 645-661.

McGowan, P., Redeker, C. L., Cooper, S. Y., and Greenan, K. 2012. "Female entrepreneurship and the management of business and domestic roles: Motivations, expectations and realities". Entrepreneurship \& Regional Development, 24(1-2): 53 72.

McKeever, E., Jack, S., and Anderson, A. 2015. "Embedded entrepreneurship in the creative re-construction of place". Journal of Business Venturing, 30(1): 50-65.

Metcalf, H. 2013. "Hidden unemployment and the labour market", Understanding unemployment: 173-193: Routledge.

Naudé, W., Gries, T., Wood, E., and Meintjies, A. 2008. "Regional determinants of entrepreneurial start-ups in a developing country". Entrepreneurship and Regional Development, 20(2): 111-124.

Neter, J., Kutner, M. H., Nachtsheim, C. J., and Wasserman, W. 1996. Applied linear statistical models (4th ed.). Boston: Irwin.

Noble, M., McLennan, D., Wilkinson, K., Whitworth, A., Barnes, H., and Dibben, C. 2008. The English Indices of Deprivation. London: Communities and Local Government.

Northern Ireland Statistics and Research Agency. Northern Irelnad Multiple Deprivation Measure.

Olsen, W., Gash, V., Kim, S., and Zhang, M. 2018. The gender pay gap in the UK: evidence from the UKHLS: Government Equalities Office.

Passaro, R., Quinto, I., and Thomas, A. 2018. "The impact of higher education on entrepreneurial intention and human capital". Journal of Intellectual Capital, 19(1): 135-156.

Patrick, C., Stephens, H., and Weinstein, A. 2016. "Where are all the self-employed women? Push and pull factors influencing female labor market decisions". Small Business Economics, 46(3): 365-390.

Patterson, N., and Mavin, S. 2009. "Women entrepreneurs: Jumping the corporate ship and gaining new wings". International Small Business Journal, 27(2): 173-192. 
Payne, R. A., and Abel, G. A. 2012. "UK indices of multiple deprivation-a way to make comparisons across constituent countries easier". Health Statistics Quarterly(53): 2237.

Perucca, G., Piacenza, M., and Turati, G. 2018. "Spatial inequality in access to healthcare: evidence from an Italian Alpine region". Regional Studies: 1-12.

Piantadosi, S., Byar, D. P., and Green, S. B. 1988. "The ecological fallacy". American journal of epidemiology, 127(5): 893-904.

Piperopoulos, P., and Dimov, D. 2015. "Burst bubbles or build steam? Entrepreneurship education, entrepreneurial self-efficacy, and entrepreneurial intentions". Journal of Small Business Management, 53(4): 970-985.

Poggesi, S., Mari, M., and De Vita, L. 2016. "What's new in female entrepreneurship research? Answers from the literature". International Entrepreneurship and Management Journal, 12(3): 735-764.

Rae, A. 2012. "Spatially concentrated deprivation in England: An empirical assessment". Regional Studies, 46(9): 1183-1199.

Ram, M., Jones, T., Edwards, P., Kiselinchev, A., Muchenje, L., and Woldesenbet, K. 2013. "Engaging with super-diversity: New migrant businesses and the researchpolicy nexus". International Small Business Journal, 31(4): 337-356.

Ram, M., Theodorakopoulos, N., and Jones, T. 2008. "Forms of capital, mixed embeddedness and Somali enterprise". Work, Employment and Society, 22(3): 427446.

Rauch, A., and Rijsdijk, S. A. 2013. "The Effects of General and Specific Human Capital on Long-Term Growth and Failure of Newly Founded Businesses". Entrepreneurship Theory and Practice, 37(4): 923-941.

Reuschke, D., Mason, C., Syrett, S., and Van Ham, M. 2015. "Integrating entrepreneurship with urban and neighbourhood studies: lessons for future research". Entrepreneurship in cities: neighbourhoods, householdes and homes. Edward Elgar Publishing, Cheltenham: 273-285.

Reynolds, P., Bosma, N., Autio, E., Hunt, S., De Bono, N., Servais, I., Lopez-Garcia, P., and Chin, N. 2005. "Global entrepreneurship monitor: Data collection design and implementation 1998-2003". Small Business Economics, 24(3): 205-231.

Rindova, V., Barry, D., and Ketchen Jr, D. J. 2009. "Entrepreneuring as emancipation". Academy of management review, 34(3): 477-491.

Romero, M., and Valdez, Z. 2016. "Introduction to the special issue: Intersectionality and entrepreneurship". Ethnic and Racial Studies, 39(9): 1553-1565. 
Roper, S., and Scott, J. M. 2009. "Perceived financial barriers and the start-up decision an econometric analysis of gender differences using GEM data". International Small Business Journal, 27(2): 149-171.

Rotefoss, B., and Kolvereid, L. 2005. "Aspiring, nascent and fledgling entrepreneurs: An investigation of the business start-up process". Entrepreneurship \& Regional Development, 17(2): 109-127.

Rouse, J., and Jayawarna, D. 2006. "The financing of disadvantaged entrepreneurs: are enterprise programmes overcoming the finance gap?". International Journal of Entrepreneurial Behavior \& Research, 12(6): 388-400.

Rouse, J., and Jayawarna, D. 2011. "Structures of exclusion from enterprise finance". Environment and Planning-Part C, 29(4): 659-676.

Runyan, R. C., Huddleston, P., and Swinney, J. 2006. "Entrepreneurial orientation and social capital as small firm strategies: A study of gender differences from a resourcebased view". The International Entrepreneurship and Management Journal, 2(4): 455.

Sahasranamam, S. and Ball, C. 2016. "Sustainable procurement in social enterprises: Comparative case studies from India and Scotland". Implementing Triple Bottom Line Sustainability into Global Supply Chains (Eds. Lydia Bals and Wendy Tate), Greenleaf Publishing, 219-231.

Sahasranamam, S. and Ball, C. 2018, "Influence of national business system on social enterprises in Scotland and India". Research Handbook on Small Business Social Responsibility: Global Perspectives (Eds. Laura J. Spence, Jedrzej George Frynas, Judy Muthuri and Jyoti Navare), Edward Elgar, 23-46.

Sahasranamam, S., \& Nandakumar, M. K. 2018. "Individual capital and social entrepreneurship: Role of formal institutions". Journal of Business Research, forthcoming.

Sahasranamam, S., \& Raman, G. V. 2018. "Individual resources, property rights and entrepreneurship in China". International Journal of Emerging Markets, 13(6): 15021521.

Sahasranamam, S., and Sud, M. 2016. "Opportunity and necessity entrepreneurship: A comparative study of India and China". Academy of Entrepreneurship Journal, 22(1): $21-40$.

Santos, F. J., Roomi, M. A., and Liñán, F. 2016. "About gender differences and the social environment in the development of entrepreneurial intentions". Journal of Small Business Management, 54(1): 49-66.

Shane, S. 2000. "Prior knowledge and the discovery of entrepreneurial opportunities". Organization Science, 11(4): 448-469. 
Slack, J. 2005. "The new entrepreneur scholarships: self-employment as a means to tackle social deprivation". Education + Training, 47(6): 447-455.

Spigel, B. 2017. "The relational organization of entrepreneurial ecosystems". Entrepreneurship Theory and Practice, 41(1): 49-72.

Stam, E. 2015. "Entrepreneurial ecosystems and regional policy: a sympathetic critique". European Planning Studies, 23(9): 1759-1769.

Stats Wales. Welsh Index of Multiple Deprivation.

Stephens, H. M., Partridge, M. D., and Faggian, A. 2013. "Innovation, entrepreneurship and economic growth in lagging regions". Journal of Regional Science, 53(5): 778812.

Storey, D. J., and Johnson, S. 1987. "Regional variations in entrepreneurship in the UK". Scottish Journal of Political Economy, 34(2): 161-173.

Stuetzer, M., Audretsch, D. B., Obschonka, M., Gosling, S. D., Rentfrow, P. J., and Potter, J. 2018. "Entrepreneurship culture, knowledge spillovers and the growth of regions". Regional Studies, 52(5): 608-618.

Sutter, C., Bruton, G. D., and Chen, J. 2019. "Entrepreneurship as a solution to extreme poverty: A review and future research directions". Journal of Business Venturing, 34(1): 197-214.

Taylor, M., and Plummer, P. 2003. "Promoting local economic growth: the role of entrepreneurship and human capital". Education+ Training, 45(8/9): 558-563.

The Baroness Mone OBE. 2016. Boosting enterprise in more deprived communities.

The Scottish Government. Scottish Index of Multiple Deprivation.

Thiess, D., Vogel, P. M., Grichnik, D., and Brinckmann, J. 2015. Is More Always Better? Re-Assessing the Role of Human Capital in Entrepreneurship. Paper presented at the Academy of Management Proceedings.

Thompson, P., Jones-Evans, D., and Kwong, C. 2008. "Entrepreneurship and the Domains of Deprivation in Wales". Regional Studies Association International on Regions: The Dilemmas of Integration and Competition, Prague: 27-29.

Ucbasaran, D., Westhead, P., and Wright, M. 2008. "Opportunity identification and pursuit: does an entrepreneur's human capital matter?". Small Business Economics, 30(2): 153-173.

UK Data Service Census Support. GeoConvert.

UK Women's Enterprise Taskforce. 2012. Greater Return on Women's Enterprise. 
Unger, J. M., Rauch, A., Frese, M., and Rosenbusch, N. 2011. "Human capital and entrepreneurial success: A meta-analytical review". Journal of Business Venturing, 26(3): 341-358.

Urbano, D., and Alvarez, C. 2014. "Institutional dimensions and entrepreneurial activity: an international study". Small Business Economics, 42(4): 703-716.

van der Zwan, P., Thurik, R., Verheul, I., and Hessels, J. 2016. "Factors influencing the entrepreneurial engagement of opportunity and necessity entrepreneurs". Eurasian Business Review, 6(3): 273-295.

Vuong, Q. H., Do, T. H., and Vuong, T. T. 2016. "Resources, experience, and perseverance in entrepreneurs' perceived likelihood of success in an emerging economy". Journal of Innovation and Entrepreneurship, 5(1): 18.

Vuong, Q. H., Tran, T. D., and Napier, N. K. 2013. "A categorical data analysis on relationships between culture, creativity and business stage: the case of Vietnam". International Journal: Transitions and Innovation Systems, 3(1): 4-24.

Wang, Y., and Warn, J. 2018. "Chinese immigrant entrepreneurship: Embeddedness and the interaction of resources with the wider social and economic and context". International Small Business Journal, 36(2): 131-148.

Welter, F., Trettin, L., and Neumann, U. 2008. "Fostering entrepreneurship in distressed urban neighbourhoods". International Entrepreneurship and Management Journal, 4(2): 109-128.

Williams, N., and Huggins, R. 2013. "Supporting entrepreneurship in deprived communities: a vision too far?". Journal of Small Business and Enterprise Development, 20(1): 165-180.

Williams, N., Huggins, R., and Thompson, P. 2017. "Entrepreneurship and Social Capital: Examining the Association in Deprived Urban Neighbourhoods". International Journal of Urban and Regional Research.

Williams, N., and Williams, C. 2017. "2. Entrepreneurship and deprived urban areas: understanding activity and the hidden enterprise culture". Entrepreneurial Neighbourhoods: 21.

Williams, N., and Williams, C. C. 2011. "Tackling barriers to entrepreneurship in a deprived urban neighbourhood". Local Economy, 26(1): 30-42.

Zelner, B. A. 2009. "Using simulation to interpret results from logit, probit, and other nonlinear models". Strategic Management Journal, 30(12): 1335-1348.

Zolin, R., Stuetzer, M., and Watson, J. 2013. "Challenging the female underperformance hypothesis". International Journal of Gender and Entrepreneurship, 5(2): 116-129. 
Figure 1 Conceptual model (unit of analysis is geographical locales)

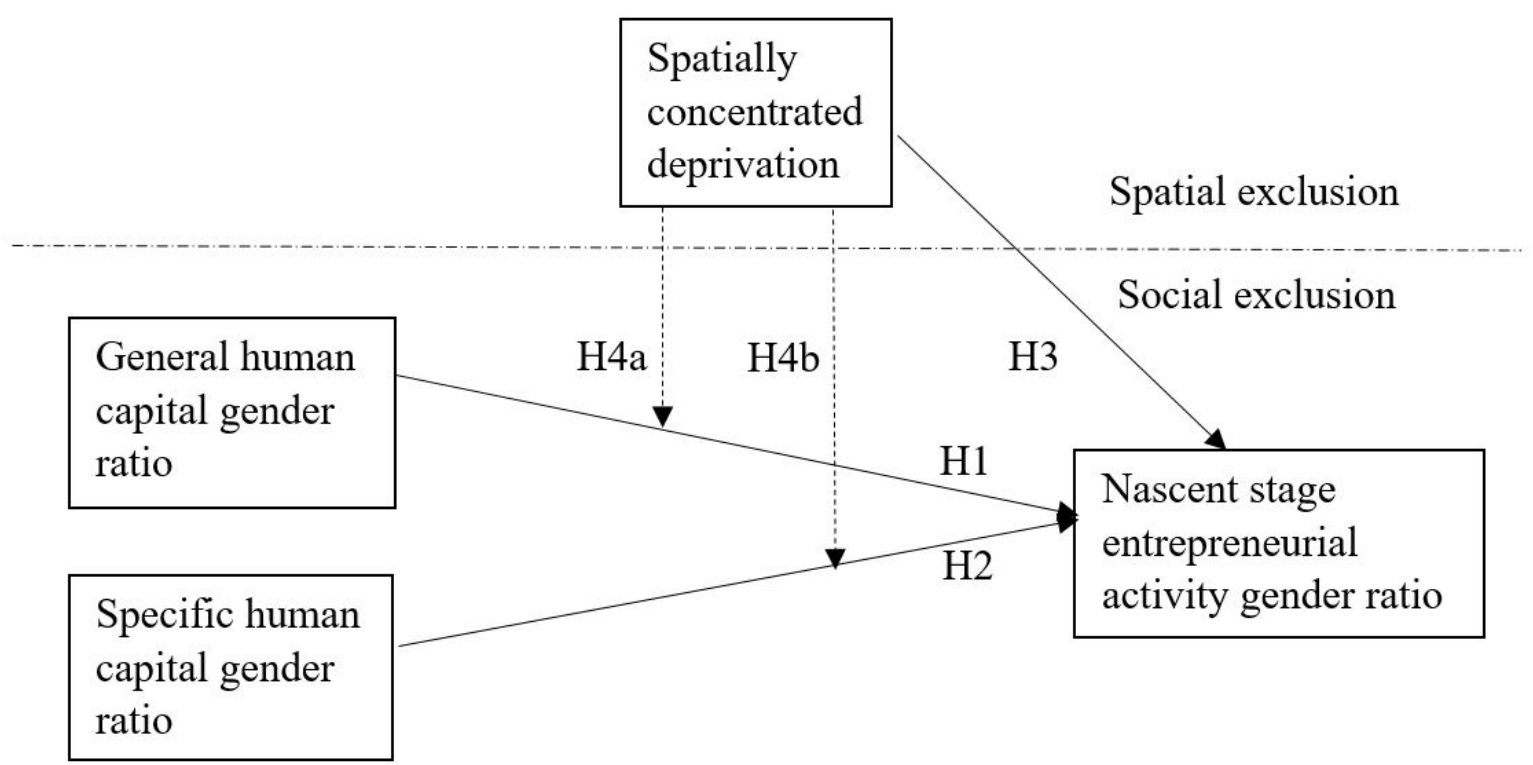


Table 1 Estimations of the regression models for the Indices of Multiple Deprivation in England, Scotland, Wales, and Northern Ireland.

\begin{tabular}{|c|c|c|c|c|c|c|c|}
\hline & \multicolumn{2}{|c|}{ England } & \multicolumn{2}{|c|}{ Scotland } & \multicolumn{2}{|c|}{ Wales } & \multirow{2}{*}{$\begin{array}{c}\text { Northern } \\
\text { Ireland }\end{array}$} \\
\hline & 2007 & 2010 & 2006 & 2012 & 2008 & 2011 & \\
\hline Constant & -0.50 & -0.19 & -0.79 & -1.62 & 6.02 & 5.42 & -6.60 \\
\hline Income Domain coefficient & 0.71 & 0.85 & 0.89 & 0.89 & 0.46 & 0.27 & 0.72 \\
\hline $\begin{array}{l}\text { Employment Domain } \\
\text { coefficient }\end{array}$ & 1.09 & 0.93 & 0.76 & 0.83 & 0.26 & 0.48 & 0.76 \\
\hline $\begin{array}{l}\text { Estimated standard deviation } \\
\text { of the residuals }\end{array}$ & 3.52 & 3.59 & 2.73 & 3.09 & 3.19 & 2.77 & 2.86 \\
\hline Number of observations & \multicolumn{2}{|c|}{32481} & \multicolumn{2}{|c|}{6504} & \multicolumn{2}{|c|}{1895} & 889 \\
\hline
\end{tabular}


Table 2 Summary statistics for spatially aggregated communities

\begin{tabular}{lr}
\hline Overall Statistics & \\
\hline Number of observations in the sample & 135825 \\
Number of LSOAs/data zones/super output areas in the sample & 33589 \\
Number of communities in the sample & 197 \\
\hline Communities Statistics & 171 \\
\hline Mean number of LSOAs/data zones/super output areas & 102.7 \\
S.D. of the number of LSOAs/data zones/super output areas & 17 \\
Minimum number of LSOAs/data zones/super output areas & 456 \\
Maximum number of LSOAs/data zones/super output areas & 690 \\
Mean number of observations & 639 \\
Minimum number of observations & 737 \\
Maximum number of observations & 7.4 \\
S.D. of the number of observations & 25.3 \\
\hline IMD Statistics across Communities & 10.4 \\
\hline Average mean IMD & 8.5 \\
S.D. of mean IMD & 67.5 \\
Minimum mean IMD
\end{tabular}


Table 3 Sample characteristics across four nations in the UK

\begin{tabular}{lccc}
\hline & $\begin{array}{c}\text { Number of } \\
\text { LSOAs/data } \\
\text { zones/super output } \\
\text { areas }\end{array}$ & $\begin{array}{c}\text { Number of } \\
\text { communities }\end{array}$ & $\begin{array}{c}\text { Number of } \\
\text { observations }\end{array}$ \\
\hline England & 25639 & 118 & 85727 \\
Wales & 5083 & 32 & 24172 \\
Scotland & 1962 & 30 & 12771 \\
Northern Ireland & 905 & 17 & 13155 \\
\hline Total & $\mathbf{3 3 5 8 9}$ & $\mathbf{1 9 7}$ & $\mathbf{1 3 5 8 2 5}$ \\
\hline
\end{tabular}


Table 4 Variable operationalization and summary statistics

\begin{tabular}{|c|c|c|c|}
\hline \multirow{2}{*}{\multicolumn{4}{|c|}{$\begin{array}{l}\text { Variable } \\
\text { Dependent } \\
\text { variable }\end{array}$}} \\
\hline & & & \\
\hline $\begin{array}{l}\text { Nascent stage } \\
\text { entrepreneurial } \\
\text { activity gender } \\
\text { ratio } \\
\text { Independent } \\
\text { variables }\end{array}$ & $\begin{array}{l}\text { Ratio of female total nascent entrepreneurial } \\
\text { activity rate over male nascent entrepreneurial } \\
\text { activity rate among } 18-64 \text { year old adult } \\
\text { population at the locale level }\end{array}$ & 0.86 & 0.61 \\
\hline $\begin{array}{l}\text { General human } \\
\text { capital gender } \\
\text { ratio }\end{array}$ & $\begin{array}{l}\text { Ratio of female post-secondary education } \\
\text { completion rate over male rate among 18-64 year } \\
\text { old adult population at the locale level }\end{array}$ & 1.43 & 0.31 \\
\hline $\begin{array}{l}\text { Specific human } \\
\text { capital gender } \\
\text { ratio }\end{array}$ & $\begin{array}{l}\text { Ratio of female entrepreneurial specific } \\
\text { knowledge perception rate over male rate among } \\
18-64 \text { year old adult population at the locale level }\end{array}$ & 0.85 & 0.12 \\
\hline $\begin{array}{l}\text { Spatially } \\
\text { concentrated } \\
\text { deprivation } \\
\text { Control variables }\end{array}$ & $\begin{array}{l}\text { Mean value of Index of Multiple Deprivation at } \\
\text { the locale level }\end{array}$ & 26.22 & 11.59 \\
\hline Age & Mean age of respondents at the locale level & 45.05 & 1.31 \\
\hline $\begin{array}{l}\text { Peer networks } \\
\text { with entrepreneurs }\end{array}$ & $\begin{array}{l}\text { Mean value of individuals knowing other } \\
\text { entrepreneurs at the locale level }\end{array}$ & 0.26 & 0.03 \\
\hline Household income & $\begin{array}{l}\text { Mean value of household income at the locale } \\
\text { level }\end{array}$ & 3.37 & 0.23 \\
\hline $\begin{array}{l}\text { Media perception } \\
\text { of } \\
\text { entrepreneurship }\end{array}$ & $\begin{array}{l}\text { Mean value of individual perception of media } \\
\text { support for entrepreneurship at the locale level }\end{array}$ & 0.51 & 0.03 \\
\hline $\begin{array}{l}\text { Status associated } \\
\text { with } \\
\text { entrepreneurship }\end{array}$ & $\begin{array}{l}\text { Mean value of individual perception of status } \\
\text { associated with entrepreneurship at the locale } \\
\text { level }\end{array}$ & 0.72 & 0.03 \\
\hline
\end{tabular}


Table 5 Correlation matrix

\begin{tabular}{llllllllll}
\hline Variables & $\mathbf{1}$ & $\mathbf{2}$ & $\mathbf{3}$ & $\mathbf{4}$ & $\mathbf{5}$ & $\mathbf{6}$ & $\mathbf{7}$ & $\mathbf{8}$ & $\mathbf{9}$ \\
\hline Nascent entrepreneurial activity gender ratio & 1 & & & & & & & & \\
General human capital gender ratio & $0.17^{*}$ & 1 & & & & & & & \\
Specific human capital gender ratio & $0.32^{*}$ & $0.33^{*}$ & 1 & & & & & & \\
Spatially concentrated deprivation & $-0.16^{*}$ & $0.10^{*}$ & $-0.14^{*}$ & 1 & & & & & \\
Age & $0.21^{*}$ & $0.07^{*}$ & $0.19^{*}$ & $-0.23^{*}$ & 1 & & & & \\
Social capital with entrepreneurs & -0.00 & $0.01^{*}$ & $0.13^{*}$ & $-0.29^{*}$ & $-0.06^{*}$ & 1 & & & \\
Household income & $0.05^{*}$ & $-0.19^{*}$ & $0.02^{*}$ & $-0.61^{*}$ & $-0.04^{*}$ & $0.37^{*}$ & 1 & & \\
Media support of entrepreneurship & $0.01^{*}$ & $0.20^{*}$ & $0.09^{*}$ & $-0.14^{*}$ & $-0.08^{*}$ & $0.12^{*}$ & $-0.06^{*}$ & 1 & \\
Status associated with entrepreneurship & $-0.23^{*}$ & $0.21^{*}$ & $0.01^{*}$ & $0.17^{*}$ & $-0.38^{*}$ & $-0.05^{*}$ & $-0.09^{*}$ & $0.21^{*}$ & 1 \\
\hline
\end{tabular}

$* \mathrm{p}<0.05$ 
Table 6 Regression results on NEA gender ratio

\begin{tabular}{|c|c|c|c|c|c|c|}
\hline Variables & Model 1 & Model 2 & Model 3 & Model 4 & Model 5 & Model 6 \\
\hline $\begin{array}{l}\text { General human capital } \\
\text { gender ratio (GHC } \\
\text { gender ratio) }\end{array}$ & & $0.44^{* * *}(0.00)$ & & & $0.14^{* * *}(0.00)$ & \\
\hline $\begin{array}{l}\text { Specific human capital } \\
\text { gender ratio (SHC gender } \\
\text { ratio) }\end{array}$ & & & $1.52^{* * *}(0.01)$ & & & $0.19^{* * *}(0.00)$ \\
\hline $\begin{array}{l}\text { Spatially concentrated } \\
\text { deprivation (SCD) }\end{array}$ & & & & $-0.07^{* * *}(0.00)$ & $-0.07^{* * *}(0.00)$ & $-0.06^{* * *}(0.00)$ \\
\hline GHC gender ratio $x \mathrm{SCD}$ & & & & & $-0.04^{* * *}(0.00)$ & \\
\hline SHC gender ratio $\mathrm{x} S C D$ & & & & & & $-0.02^{* * *}(0.00)$ \\
\hline Age & $0.07^{* * *}(0.00)$ & $0.04^{* * *}(0.00)$ & $0.03^{* * *}(0.00)$ & $0.06^{* * *}(0.00)$ & $0.03^{* * *}(0.00)$ & $0.02^{* * *}(0.00)$ \\
\hline $\begin{array}{l}\text { Social capital with } \\
\text { entrepreneurs }\end{array}$ & $-0.61^{* * *}(0.05)$ & $0.93^{* * *}(0.05)$ & $-1.44^{* * *}(0.05)$ & $-1.04^{* * *}(0.05)$ & $-1.41^{* * *}(0.05)$ & $-1.83^{* * *}(0.05)$ \\
\hline Household income & $0.14^{* * *}(0.00)$ & $0.25^{* * *}(0.00)$ & $0.14^{* * *}(0.01)$ & $-0.01(0.01)$ & $0.06^{* * *}(0.01)$ & $0.02^{* *}(0.01)$ \\
\hline $\begin{array}{l}\text { Media support of } \\
\text { entrepreneurship }\end{array}$ & $1.28^{* * *}(0.06)$ & $0.74^{* * *}(0.06)$ & $0.88^{* * *}(0.05)$ & $0.90^{* * *}(0.06)$ & $0.32^{* * *}(0.06)$ & $0.52^{* * *}(0.06)$ \\
\hline $\begin{array}{l}\text { Status associated with } \\
\text { entrepreneurship }\end{array}$ & $-3.91^{* * *}(0.07)$ & $-5.01^{* * *}(0.07)$ & $-4.50^{* * *}(0.06)$ & $-3.36^{* * *}(0.07)$ & $-4.52^{* * *}(0.07)$ & $-3.89^{* * *}(0.07)$ \\
\hline \multirow[t]{2}{*}{ Constant } & $-0.32^{* *}(0.14)$ & $-0.69^{* * *}(0.14)$ & $-0.85^{* * *}(0.14)$ & $-0.44^{* *}(0.17)$ & $2.51^{* * *}(0.04)$ & $2.47^{* * *}(0.17)$ \\
\hline & \multicolumn{6}{|c|}{ Stage of the economy dummies included } \\
\hline R-squared & 0.080 & 0.126 & 0.172 & 0.087 & 0.137 & 0.179 \\
\hline F-stat & $1882.66^{* * *}$ & $3036.16^{* * *}$ & $3946.45^{* * *}$ & $1674.85^{* * *}$ & $2574.69^{* * *}$ & $3048.62^{* * *}$ \\
\hline
\end{tabular}


Figure 2a Interaction effect between spatially concentrated deprivation and general human capital gender ratio (solid line represents high value of general human capital gender ratio and dotted line represents low value of general human capital gender ratio)

\section{Linear prediction of nascent entrepreneurial gender ratio}

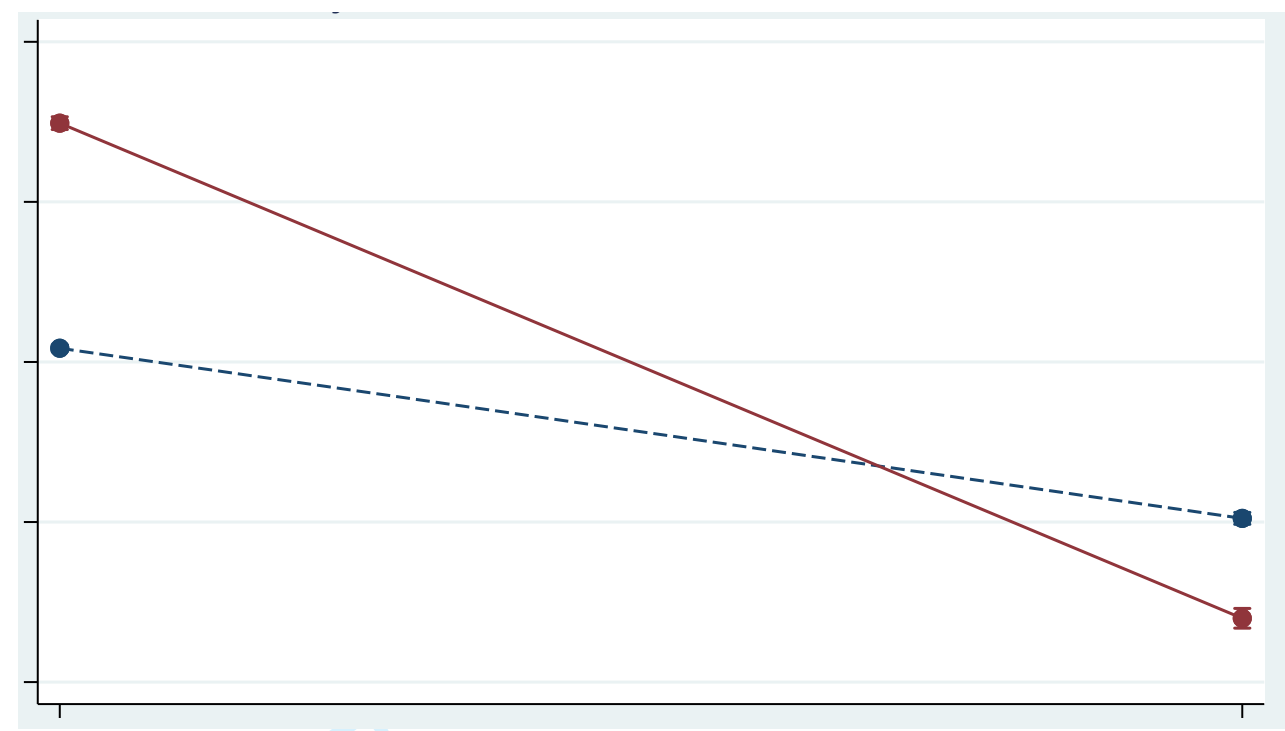

Low deprivation
High deprivation

Figure 2b Interaction effect between spatially concentrated deprivation and specific human capital gender ratio (solid line represents high value of specific human capital gender ratio and dotted line represents low value of specific human capital gender ratio)

\section{Linear prediction of nascent entrepreneurial activity gender ratio}

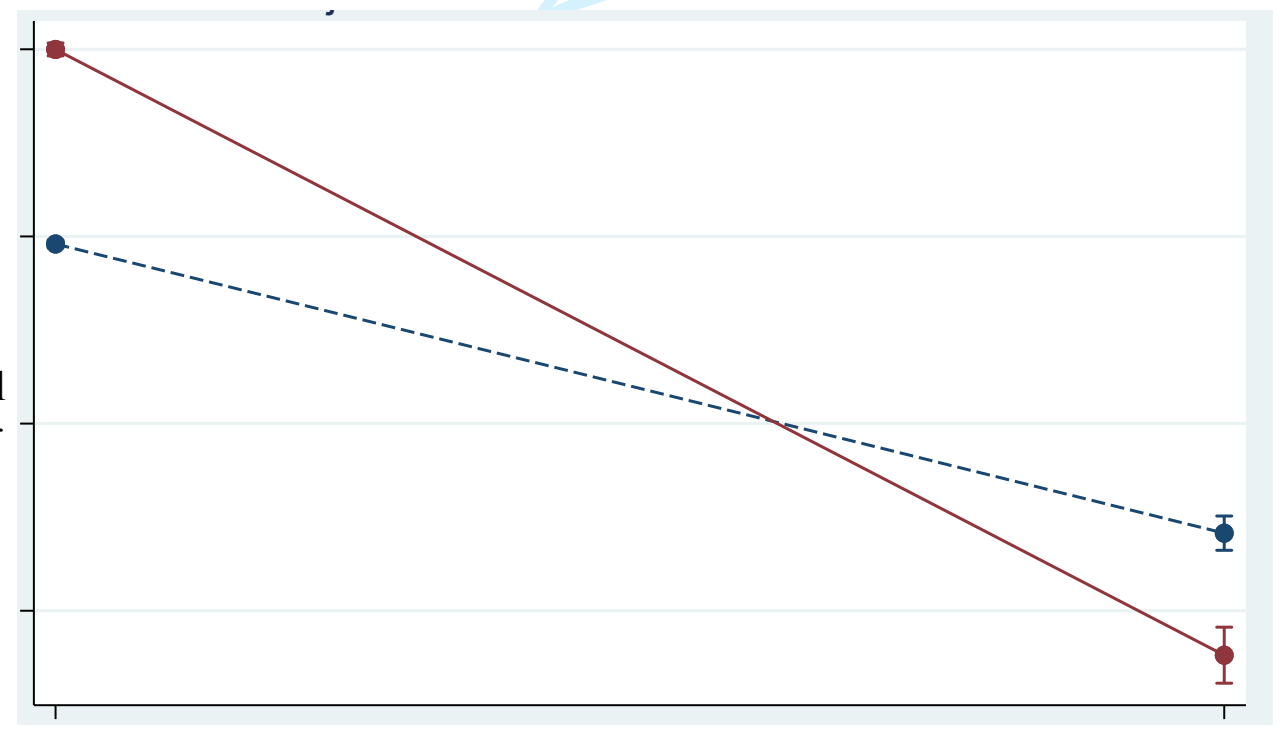

Low deprivation
High deprivation 